انتقال مجدد نيتروزن، غلظت عناصر نيتروزن، يتاسيم و فسفر گندمهاى دى، تترا و هكزايلوئيد در ياسخ به نيتروزن

\author{
سميرا فتح اللهى'، يرويز احسانزادهّ" و حسن كريم مجنى \\ (تاريخ دريافت: 1/1/10 (1/1/؛ تاريخ يذيرش: 99/1/19/1)
}

حكيده

ارتباط كاربرد كود نيتروزن با انتقال مجدد نيتروزن، غلظت عناصر فسفر، يتاسيم و نيتروزن در كندم بهخوبى شناخته شــده نيسـت. مطالعسه

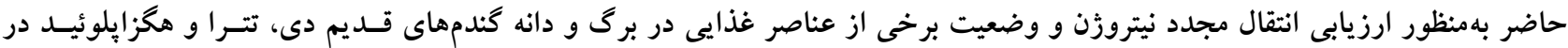

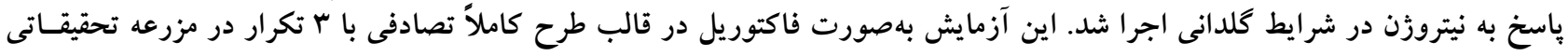

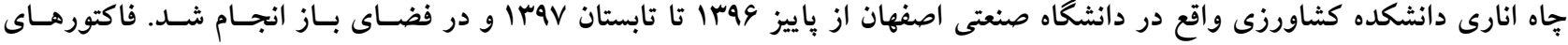

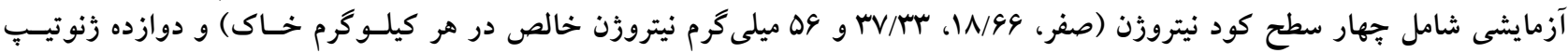

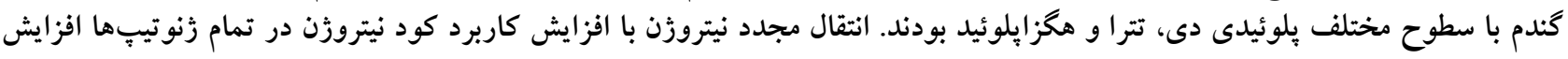

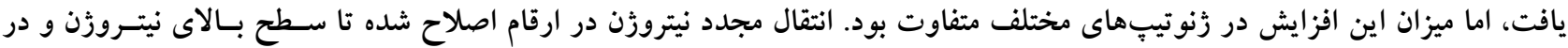

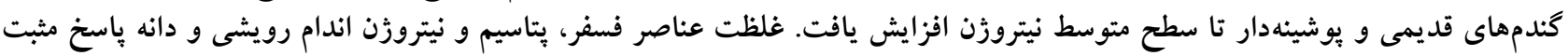

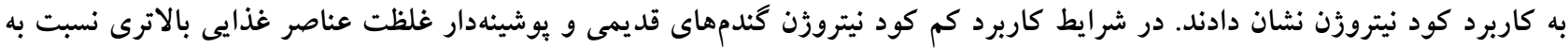

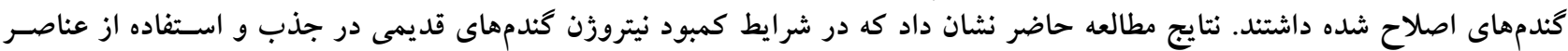

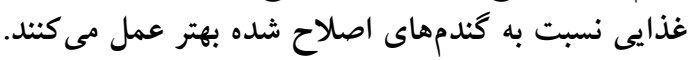

I. ا r و r. بهترتيب دانشجوى دكترى، استاد و دانشيار كروه زراعت و اصلاح نباتات دانشكده كشاورزى دانشگاه صنعتى اصفهان، اصفهان، ايران.

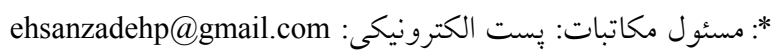


تنوع موجود در ارقام قديمى گونههاى زراعى نه تنهـا در حفـظ

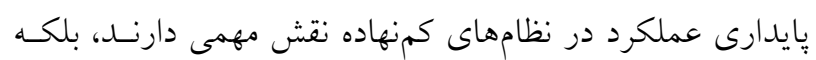

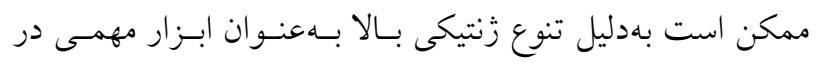

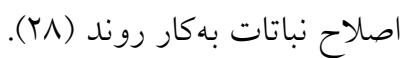
از عوامل اصلى تعيين كننده كميت و كيفيت توليدات كياهان زراعى و بـاغى مسىتـوان تقسـيمبنـدى كـربن و نيتـروزن بـين

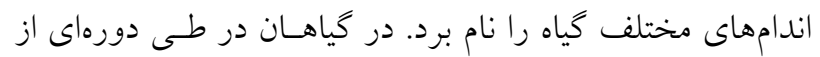
رشد، تجمع برخى از مواد توليد شده در فرايند فتوستز بيشتر از

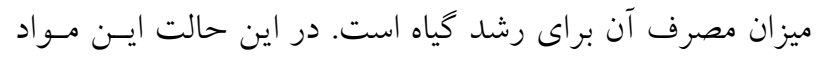

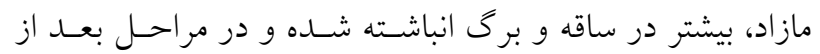

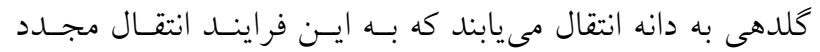
مى گويند. نيتروزن مورد نياز براى نمو دانه از طريق انتقال مجدد

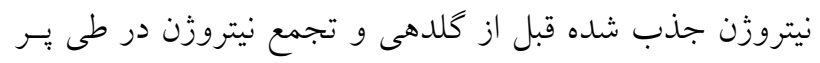

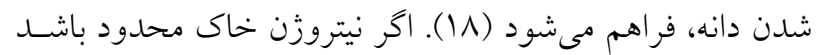

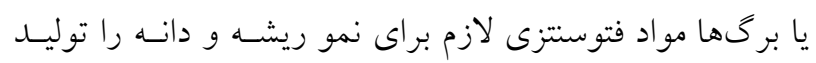

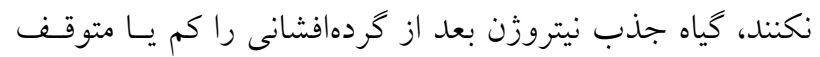

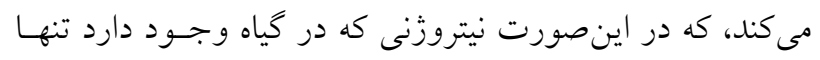

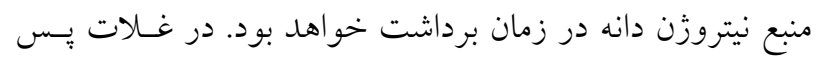

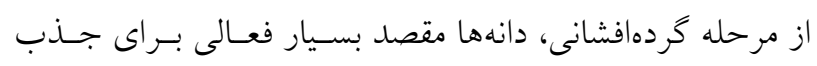

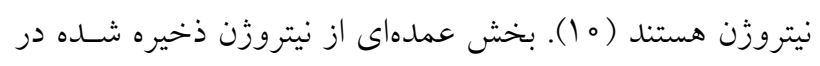

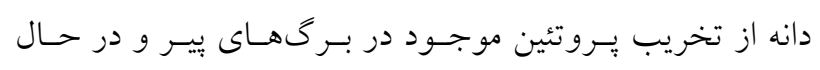

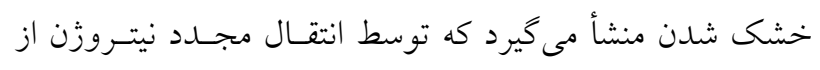

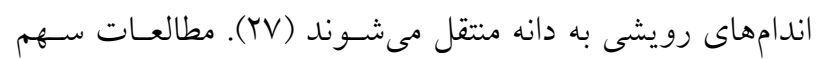

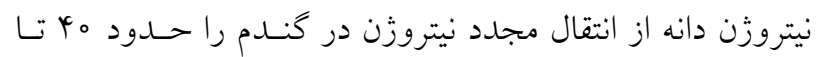
ه9 درصد كزارش كردند كه متغيــر بـودن ايسن ميـزان از انتقـال

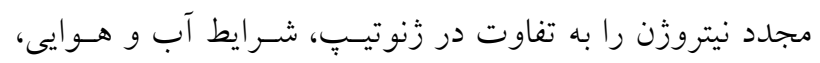

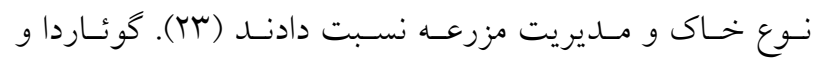

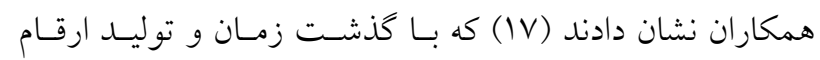

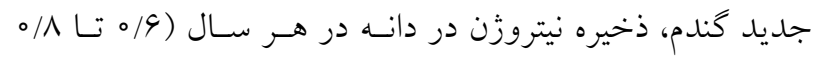
كيلوكرم در هكتار در كاربرد كسود نيتـروزن و r/ه كيلـوكرم در

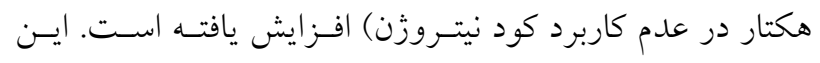

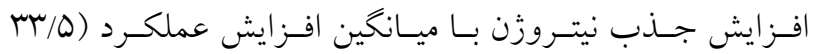

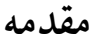

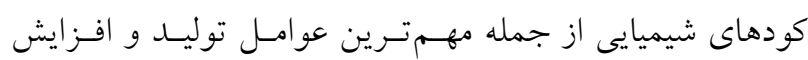

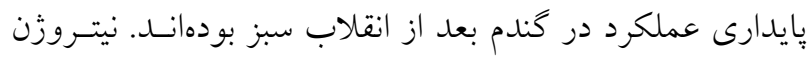

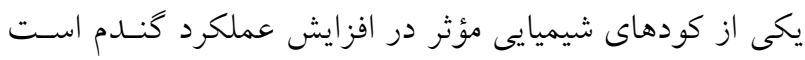

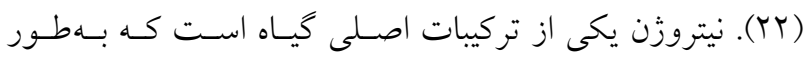

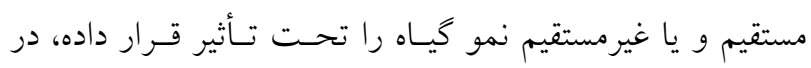

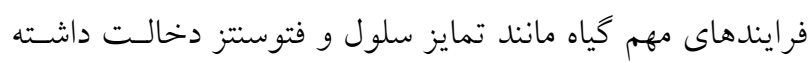

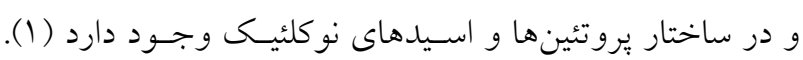

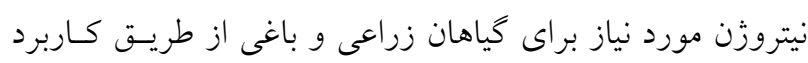

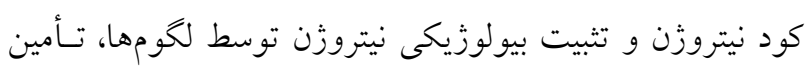

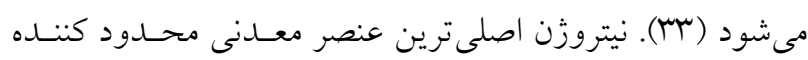

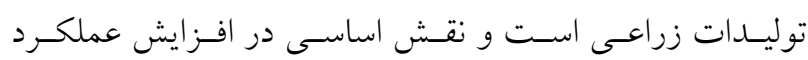
محصـول، از طريـق ايجـاد و حفـظ ظرفيـت فتوسـتنزى دارد، بههمين دليل بهصورت كودهاى شيميايى در سطح وسـيع مـورد

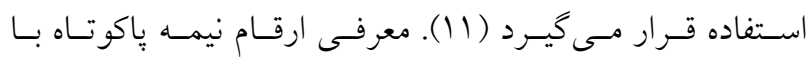
كوديذيرى بالا در دهه 1990 سهم عمدهاى در افزايش عملكـرد

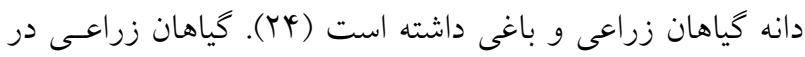
كشاورزى مدرن تحت شرايط كاربرد بيش از حد كـود نيتـروزن

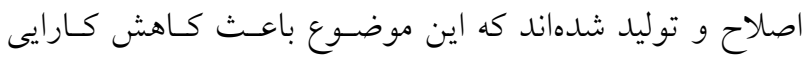

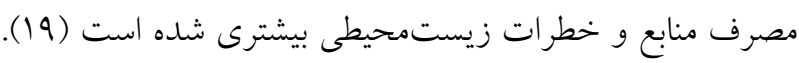

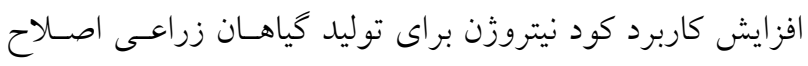

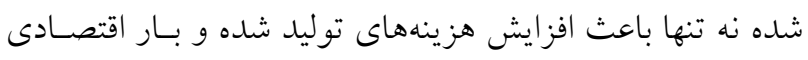

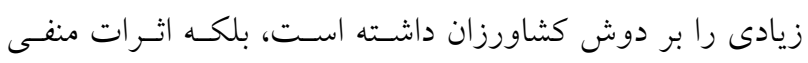

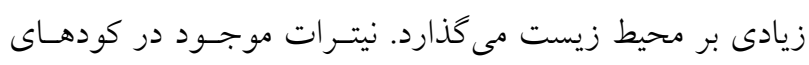

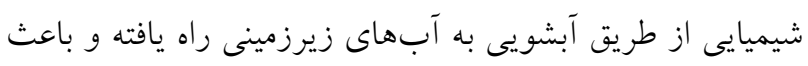

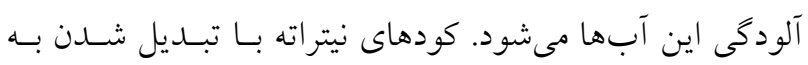

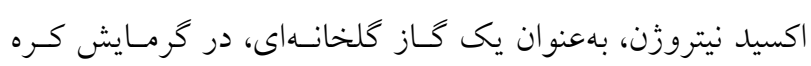

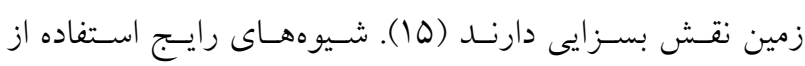

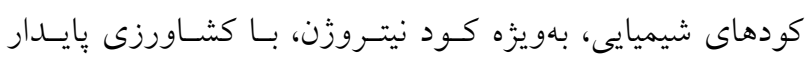

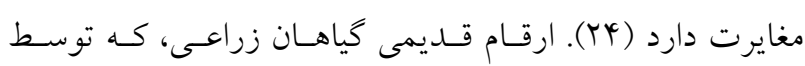

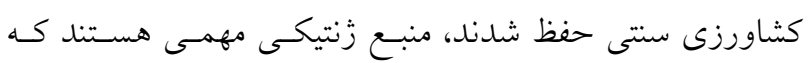
ممكن است به بركرداندن بايدارى به نظامهاى توليد كمك كنند. 
در فعاليت فتوسنتزى و در تشكيل و انتقـال كربوهيـدراتهـا و

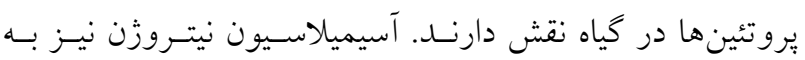

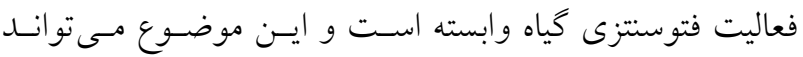

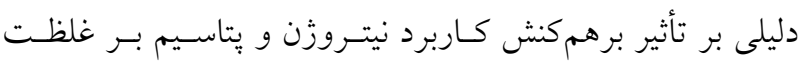

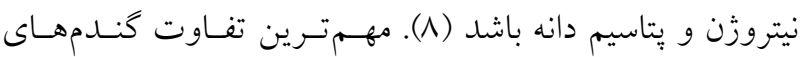

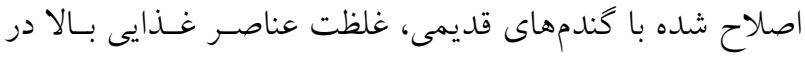

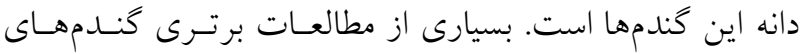
قديمى به كُندمهاى اصلاح شده را به كيفيت دانه ايسن كَنـدمهـا

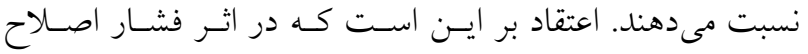
نباتات، غلظت عناصر معدنى در كُندمهاى اصلاح شـده كـاهش يافته و گندمهاى قديمى نسبت به كُندمهاى اصلاح شده عناصر

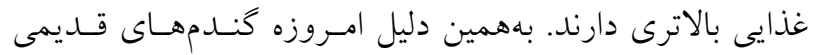

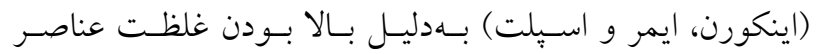

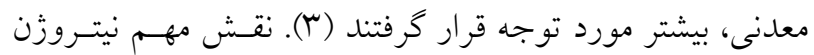

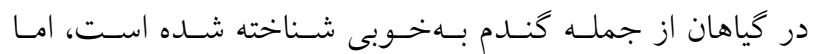

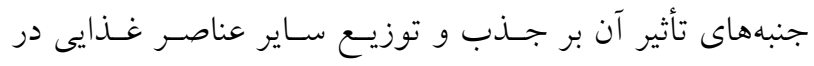

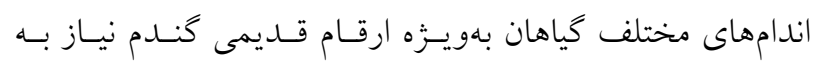

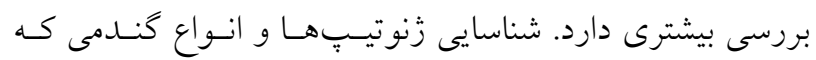

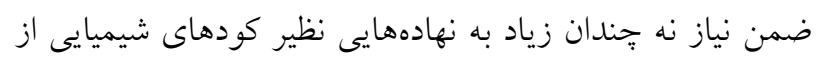

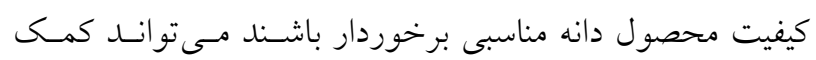

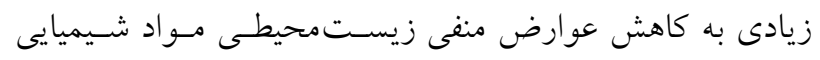

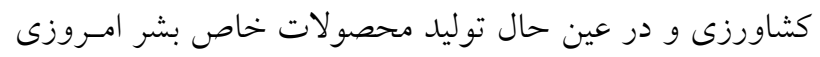

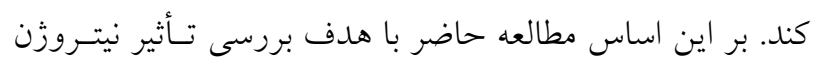

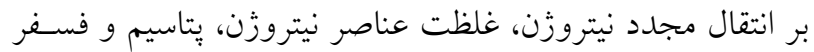

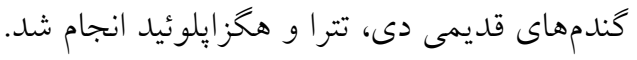

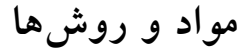
براى مقايسه انتقال مجدد نيتروزن و غلظت عناصر فسفر، يتاسيم

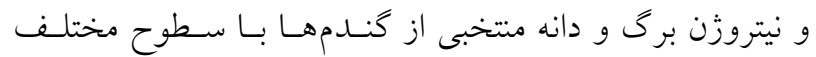

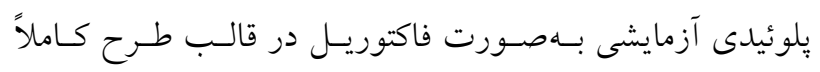

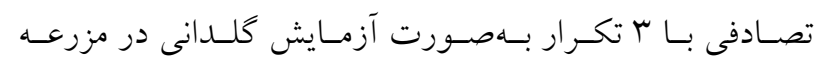

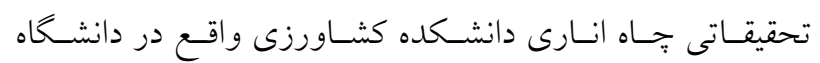

كيلوكرم در هكتـار در سـال) مطابقـت دارد. ايسن نتـايج نشـان مىدهد كه با وجود انتخاب تحت شرايط نيتروزن مطلوب، روند درند

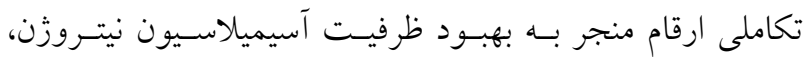

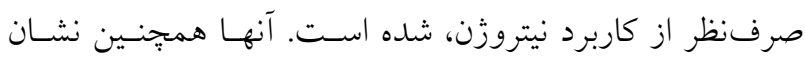

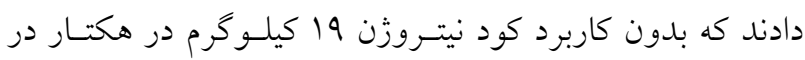

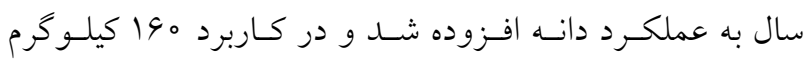
نيتروزن در هكتـار حسدود سب كيلـو گرم در هكتـار در سـال بـهـ

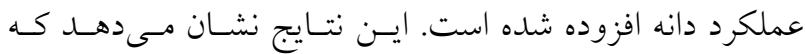

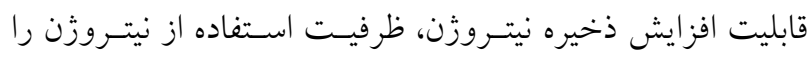
تشديد مى كند و درنتيجه توانيى گياه براى افزايش عملكرد دانه در باسخ به كاربرد نيتروزن را بالا مى برد (IV). مطالعـات انجـام

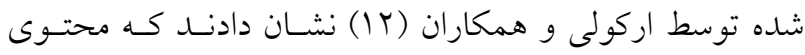
نيتروزن در تمامى قسمتهاى گياه (از جمله برگ، ساقه، ســبله

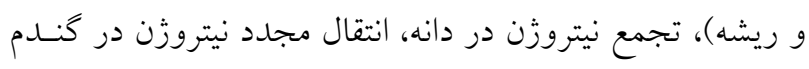

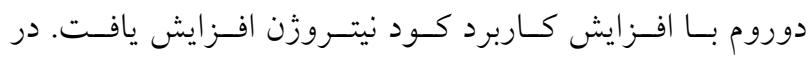

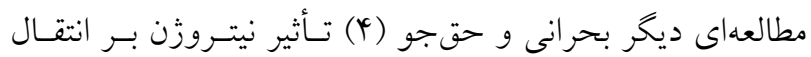

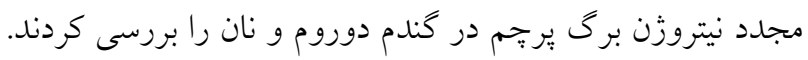

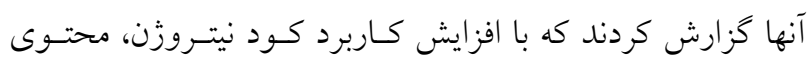

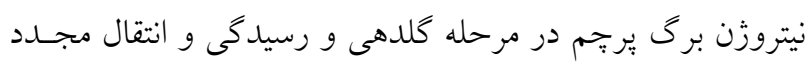

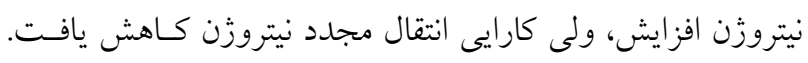

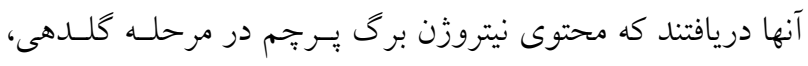

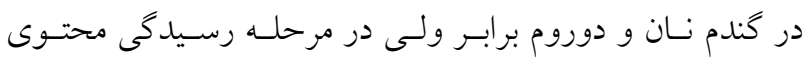

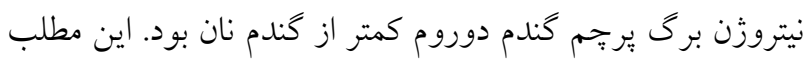

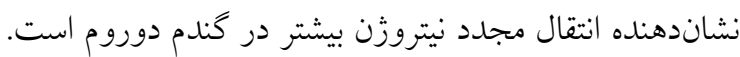
ميزان زيـادى از عناصـر غـذايى همجهـون نيتـروزن، فسـفر،

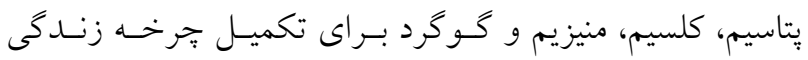

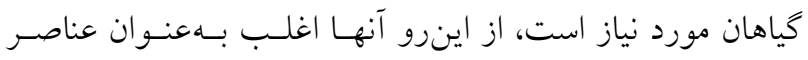

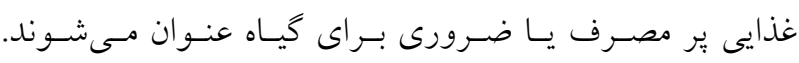

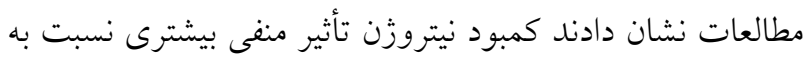

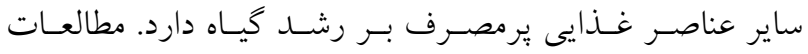
همبستخى مثبت بين كـاربرد كـود نيتـروزن و غلظـت نيتـروزن،

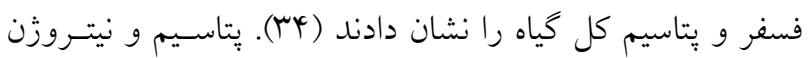


نشريه توليد و فر آورى محصولات زراعى و باغى / سال دهم / شماره جهارم / زمستان 9ه؟1

جدول ا. گُندمهاى به كار رفته در آزمايش گلدانى

\begin{tabular}{|c|c|c|c|c|c|c|}
\hline يلوئيدى سطح & 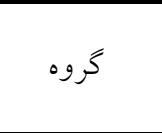 & بندى طبقه & نام علمى & نام رُنوتيِ & ن نام رايج & محل تهيه بذر \\
\hline دييلوئيد & اينكورن & قديمى & T. monococcum & TRI 565 & - & مركز تحقيقات آلمان \\
\hline \multirow{3}{*}{ تتر ايلوئيد } & قديمى & قديمى ق ق ق ق & $\begin{array}{l}\text { T. turanicum } \\
\text { T. jakubzineriu } \\
\text { T. aethiopicum }\end{array}$ & $\begin{array}{l}\text { TRI17606 } \\
\text { TRI } 12911 \\
\text { TRI } 15593 \\
\end{array}$ & خراسان & مركز مركز تحقيقات آلحقان \\
\hline & (يمش ايمر ) & قديمى ق ق ق & $\begin{array}{l}\text { T. turgidum ssp. dicoccum } \\
\text { T. turgidum ssp. dicoccum: }\end{array}$ & $\begin{array}{l}\text { Joneghan } \\
\text { Singerd }\end{array}$ & سينكرد & زاگر زمرس مركزى ايران \\
\hline & ماكارونى & جديد & $\begin{array}{c}\text { T. turgidum } \\
\text { T. turgidum var. Yavaroos }\end{array}$ & $\begin{array}{l}\text { TRI } 9652 \\
\text { Yavaroos }\end{array}$ & 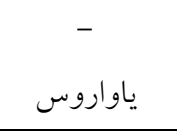 & زمركز تحقيقات آلمان \\
\hline \multirow{2}{*}{ هخز ايلوئيد } & 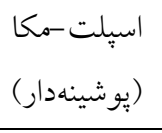 & قديمى ق ق ق ق & $\begin{array}{l}\text { T. spelta } \\
\text { T. macha }\end{array}$ & $\begin{array}{l}\text { TRI } 3429 \\
\text { TRI } 13595\end{array}$ & اسبلت & زاگر زمرس مركزى ايران \\
\hline & ن ان & جديد & $\begin{array}{c}\text { T. sphaeroccum } \\
\text { T. aestivum var. Roushan }\end{array}$ & $\begin{array}{l}\text { TRI18664 } \\
\text { Roushan }\end{array}$ & ياكوتاه هندى & زمركز تحقيقات آلمان \\
\hline
\end{tabular}

رسيدكى فيزيولوزيك يعنى مرحله 99 مقياس زادوكس بـراى

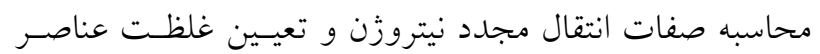
نيتروزن، يتاسيم و فسفر برداشت شدند). بـراى اعمـال تيمـار

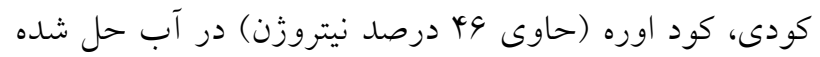

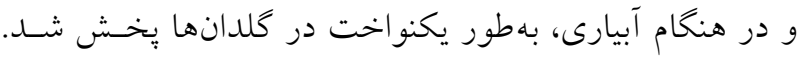

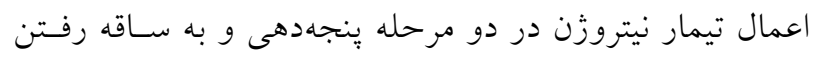

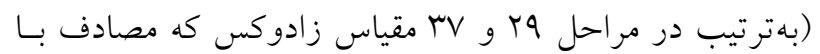

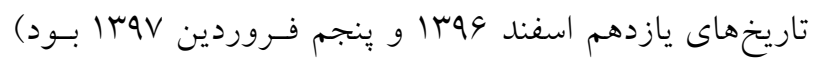

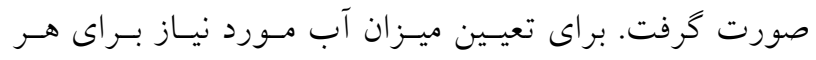

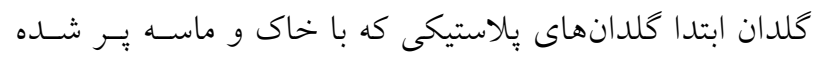

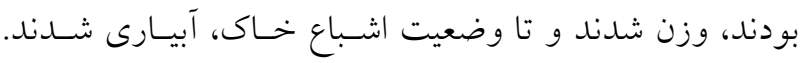

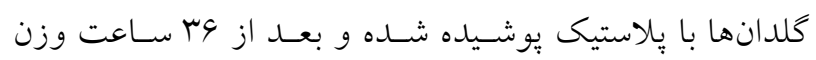

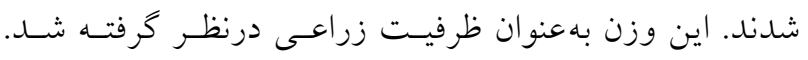
تفاوت بين وزن خاك خشك و ظرفيت زراعى بهعنوان ميـزان

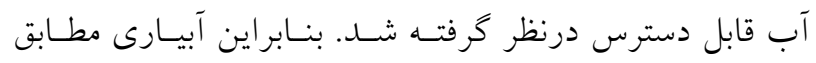

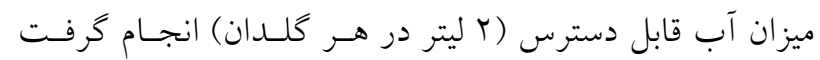

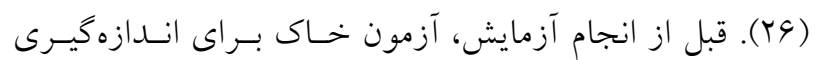

صنعتى اصفهان از يـاييز 99 تـا تابستـان $9 V$ و در فضـاى بـاز انجام شد. فاكتورهاى آزمايشى شامل جهار سطح كود نيتروزن

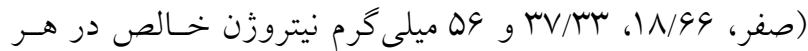
كيلو گرم خاك كه در متن براى سهولت در ارئه نتايج بهترتيب از عبارات سطح صفر، بايين، متوسط و بالاى نيتروزن اسـتفاده

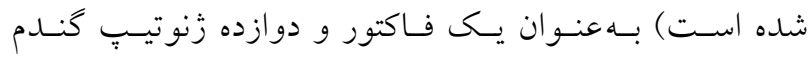
بهنوان فاكتور ديخر بودند. اين زنوتيبها شامل هفت زنوتيبٍ

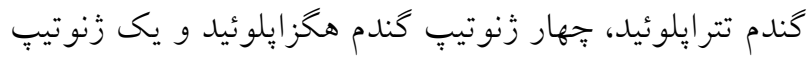

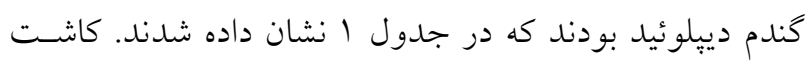

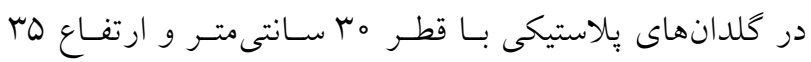

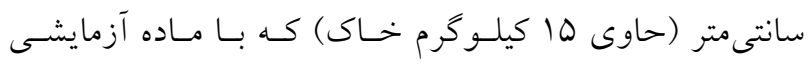
يكنو اختى شامل يك سوم ماسه و دو سـوم خـاك مزرعـهـ يـر

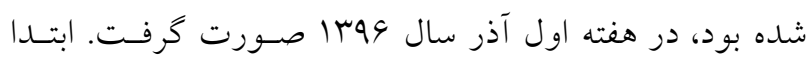
كاشت متر اكم بـــر صـورت كرفتـهـ و يـس از اسـتقر ار تعـداد بوتهها در هر كلدان به ما عدد تنكى شد (سه بوته در مرحلـه.

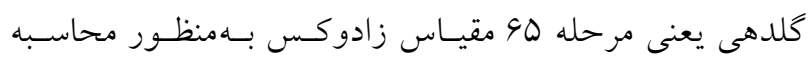
صفات انتقال مجدد نيتروزن و هفت بوته باقىمانده در مرحلـه 
اندازهگيرى غلظت عناصر فسفر و يتاسيم در بخش هوايى و دانه

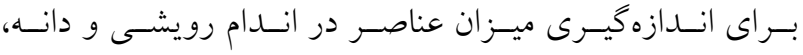
نمونسهـــردارى در مرحلـه خميـرى دانـه (مرحلـه هم مقيـاس زادو كس) صورت گرفت (^).

\section{تجزيه و تحليل آمارى} دادهها با استفاده از نرمافـزار SAS نسـخه E/4 و Excel نسـخه

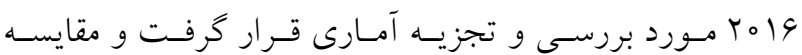
ميانكين با استفاده از آزمون LSD در سطح احتمال يـنج درصــ

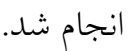

\section{نتايج و بحث}

تتايج حاصل از تجزيـهـ واريـانس دادههـا نشـان داد كـهـ اتــرات كاربرد كود نيتروزن، زنوتيتٍ و اثر برهمكـش آنهـا بـر صـفات مربوط به انتقال مجدد نيتروزن و غلظت عناصر فسفر، يتاسـيم و نيتروزن انــام رويشـى و دانـه در سـطح احتمـال يـك درصــ

$$
\text { معنى دار شد (جدول r). }
$$

محتوى نيتروزن بوته در مرحله كلـدهى و رسـيدكى بــا افـزايش كاربرد كود نيتروزن در تمام زنوتيِها افزايش يافت، ولى ميـزان ايسن افزايش در زنوتيبِهاى مختلف متفاوت بود. محتوى نيتروزن بوتـهـ در مرحله كلدهى در ارقام اصلاح شده يـاواروس و روشـن (بـهترتيـبـ

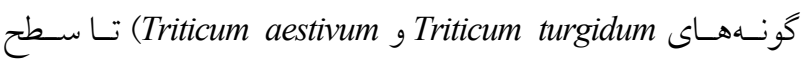
بالاى نيتروزن ( ه ميلى گرم نيتروزن خالص در هر كيلوكرم خـاك) و در ساير زنوتيڤٍ اغلب تا سطح متوسط نيتروزن (سM/VM ميلى گـرم نيتروزن خالص در هر كيلـوكرم خـاك) افـزايش يافـت (جـــول \&). بيشترين ميزان افزايش محتوى نيتـروزن بوتـه در مرحلـه كلـدهى در

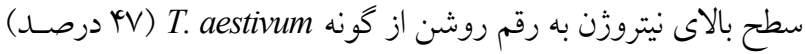
و كمترين آن در سطح متوسط نيتروزن به زنوتيبٍ تسى آر آى هوهـا

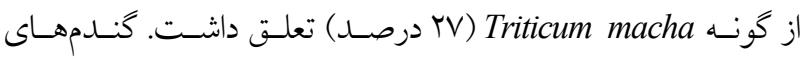
هكزايلوئيد بوشينهدار (كونسهــاى Triticum spelta و T. macha) در تمام سطوح كود نيتـروزن، بـهـــز سـطح بـالاى نيتـروزن، بيشـترين
خصوصيات خاك انجام شد (جدول Y) و با توجه به نتايج اين آزمايش كود فسفر و يتاس اسـتفاده نشـــ. برداشـت نهـايى در مرحله رسيدكى فيزيولوزيك در هفته دوم تيرماه انجام شد. انتقــال مجــد نيتـروزن: در مرحلـه كلــهـى زمـانى كـهـ

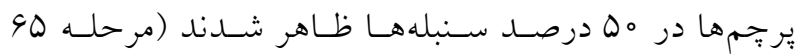
مقياس زادوكس)، بّ بوته كامل بهـور تصادفى از هر گلــان برداشت شد. نمونههاى برداشت شده بهمدت درجه حرارت Vo درجه سانتى گـراد در آون خشكى شــه و

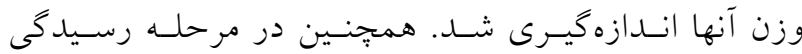
فيزيولوزيك (مرحله 99 مقياس زادوكس) نمونهبـــدارى دوم انجام و يّ از خشك كردن نمونهها مشابه نمونهبردارى اول،

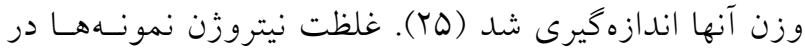
دو مرحله گلدهى و رسيدگى با دستخاه كلـدال نيمسهيكـرو اندازهذيرى شد. محتـوى نيتـروزن (semi micro Kjeldahl) بخش هوايى در مرحله گلدهى و رسـيدگى و انتقـال مجـدد نيتروزن از روابط زير محاسبه شد (r). = محتوى نيتروزن بخش رويشى در مرحله كلدهى × غلظت نيتروزن بخش رويشى در مرحله گلدهى) (وزن خشك كل اندام هوايى بوته در مرحله كلدهى

= محتوى نيتروزن بخش رويشى در مرحله رسيدگى × غلظت نيتروزن بخش رويشى بوته در مرحله رسيدگى

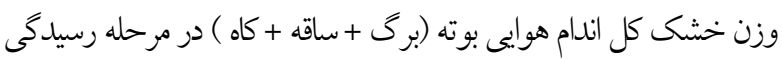
= محتوى نيتروزن دانه =

(وزن دانه در بوته × غلظت نيتروزن دانه)

= انتقال مجدد نيتروزن (ميلى گرم نيتروزن بر بوته) - محتوى نيتروزن كل اندام هوايى بوته در مرحله گلدهى محتوى نيتروزن كل اندام هوايى بوته (برى + ساقه + كاه ) در

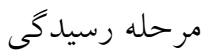




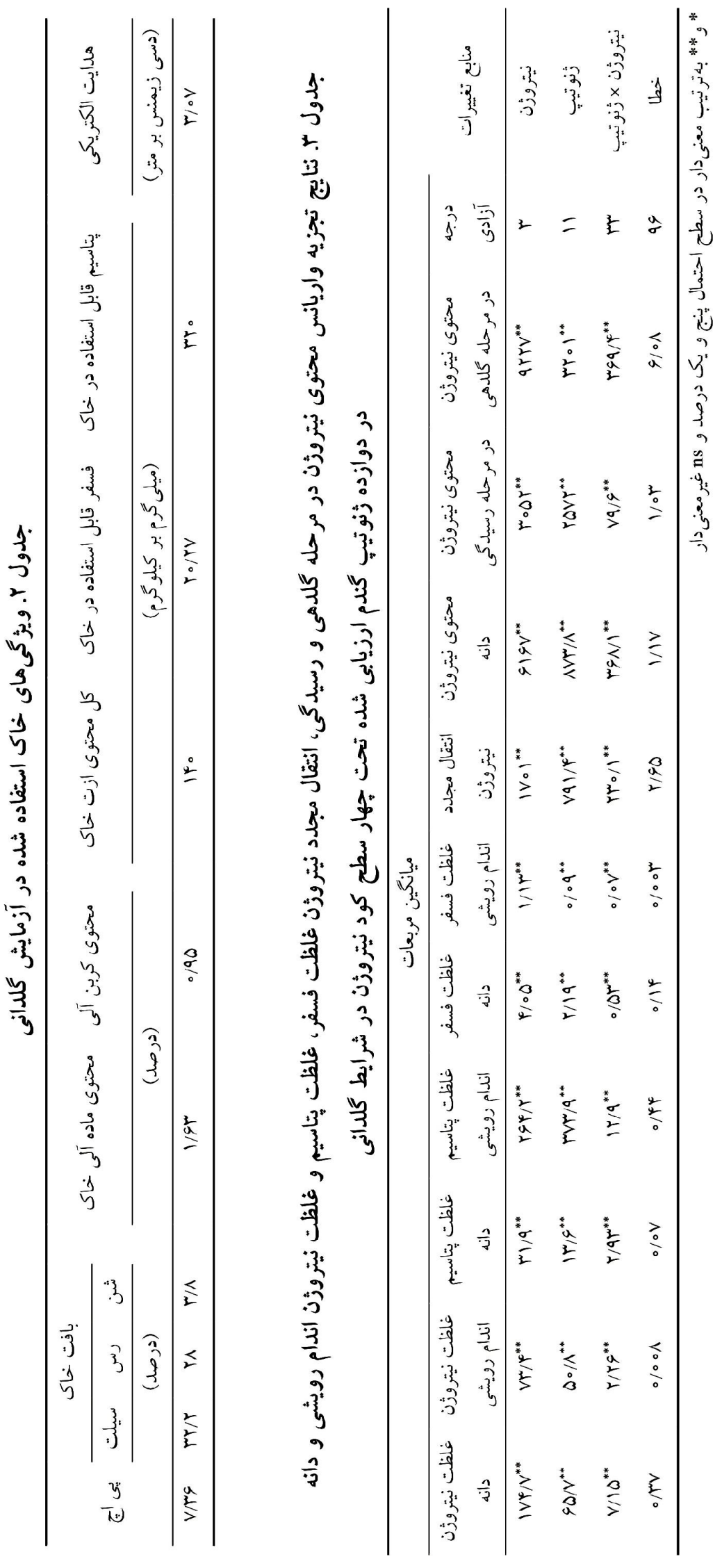




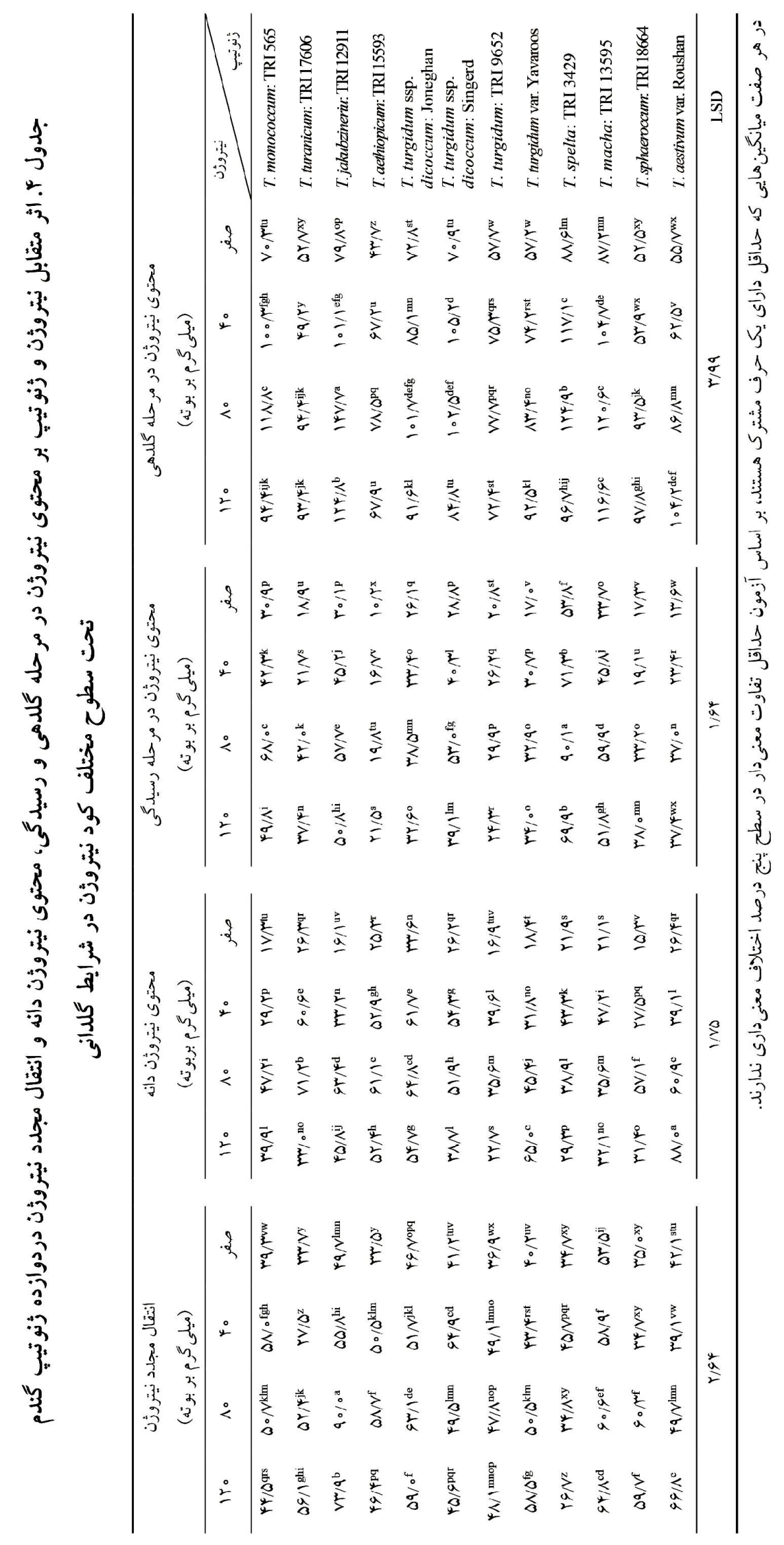


انتقال مجدد نيتروزن با افزايش كـاربرد كـود نيتـروزن در تمـام

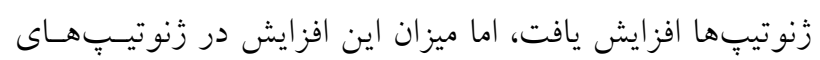

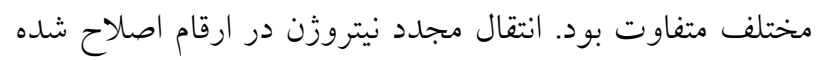

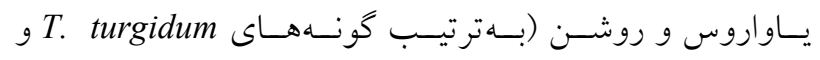

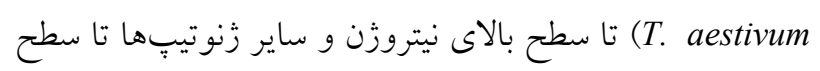

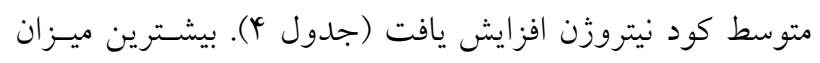

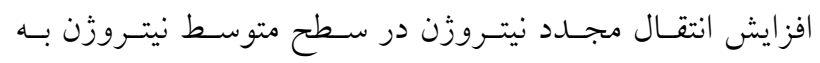

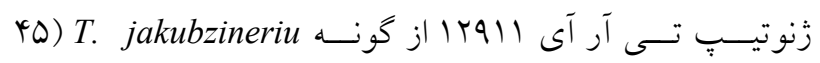

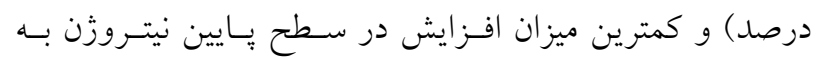

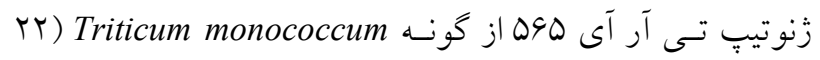

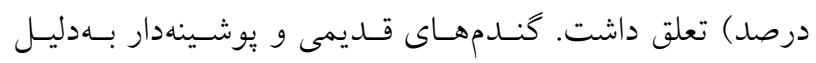

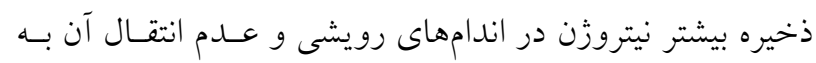

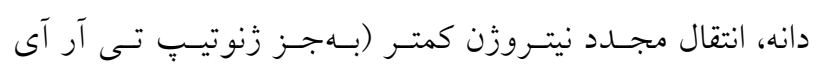

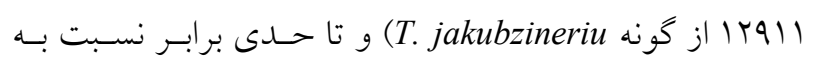

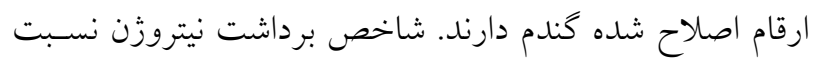

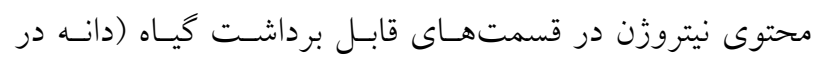

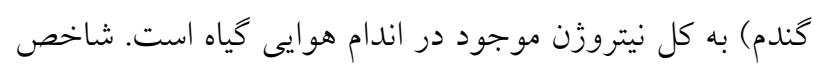

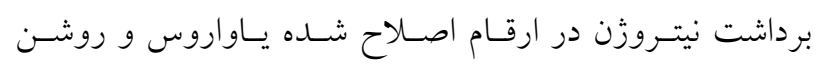

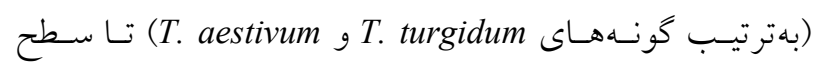

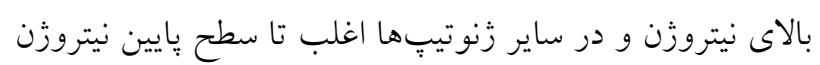

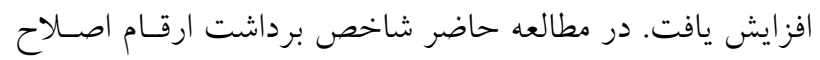

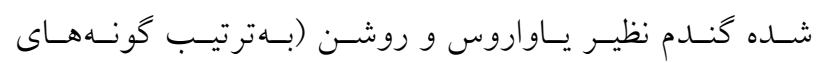

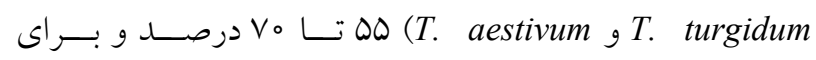

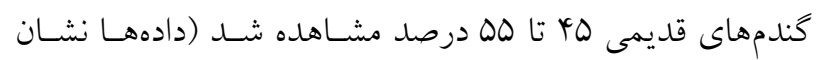

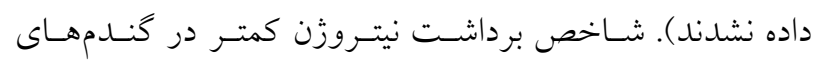

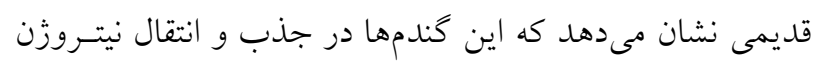

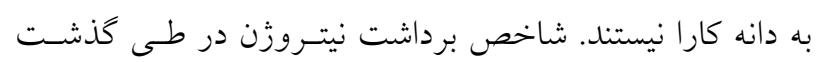

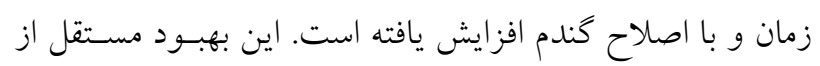

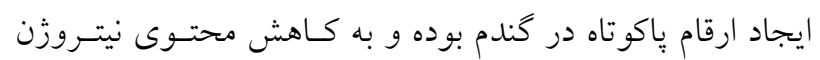

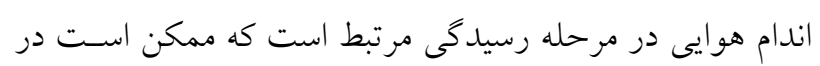

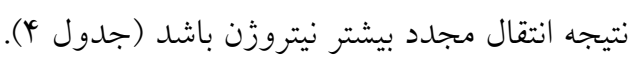

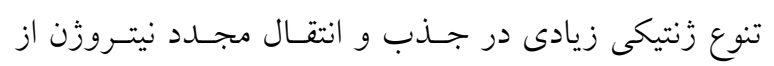

محتوى نيتروزن بوته در مرحله كلدهى را دارا بودند. افزايش محتسوى

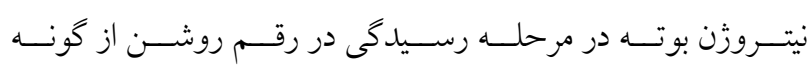

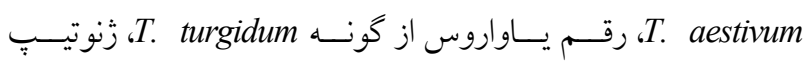

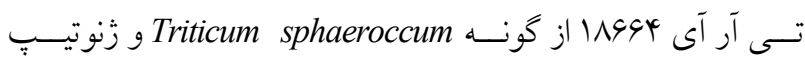

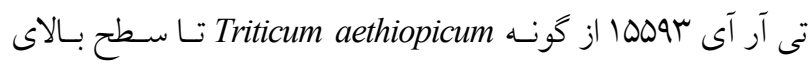

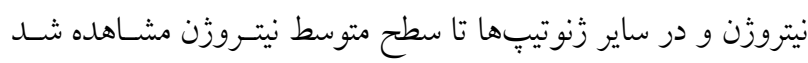

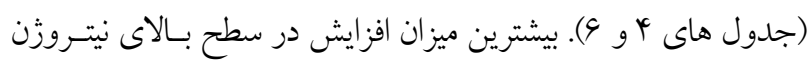

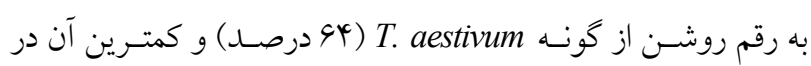

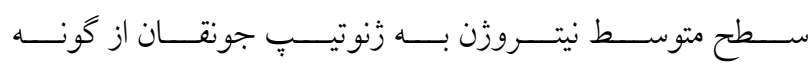

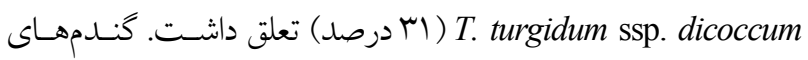

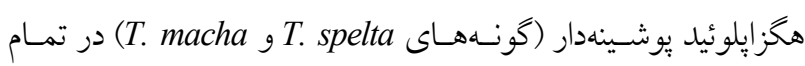

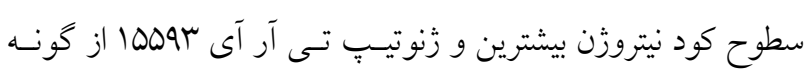
ن. aethiopicum

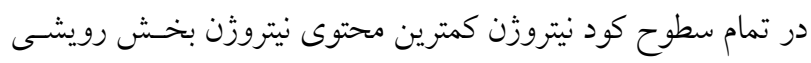
در مرحله رسيدكى را دارا بودند.

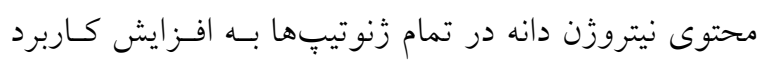

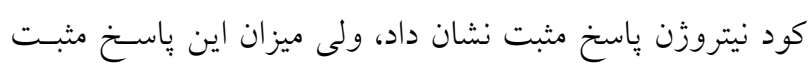

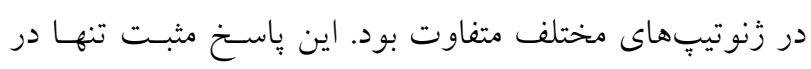

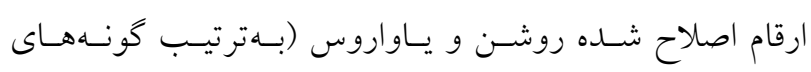

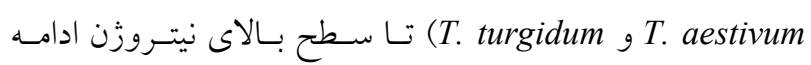

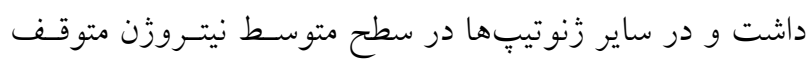

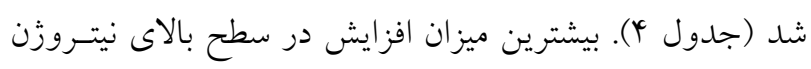

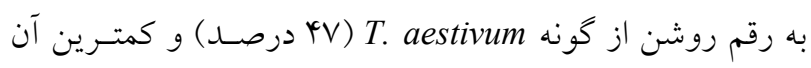

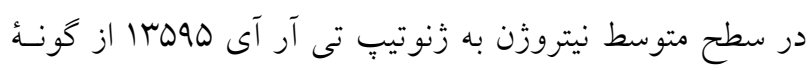
تعلق داشت. كندمهاى تتر إيلوئيد قديمى (دV) T. T. macha

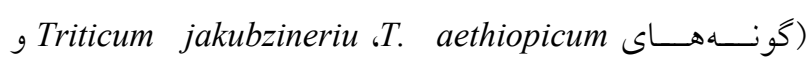

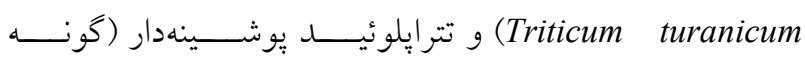

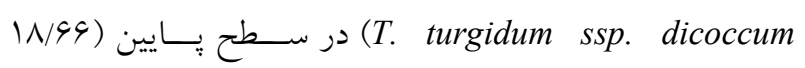

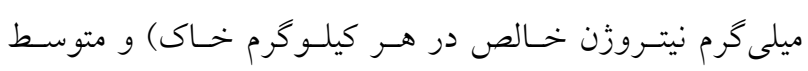

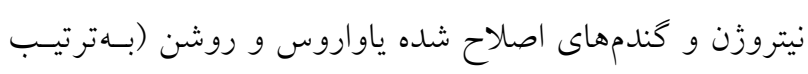

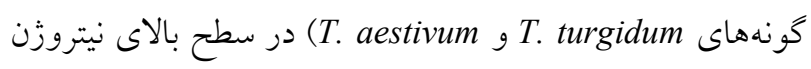
بيشترين محتوى نيتروزن دانه را دارا بودند. 
كوئلهو و همكاران (9) مشخص شد كه با افزايش كـاربرد كـود

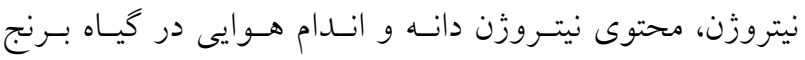

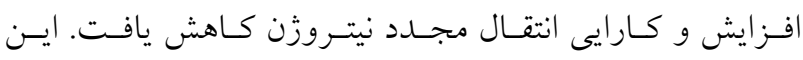
يُزوهشخران دريافتند كه محتوى نيتروزن دانه در اين كياه بـالاتر

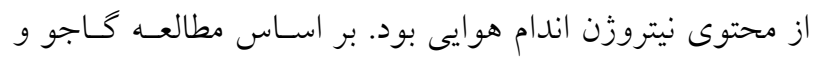

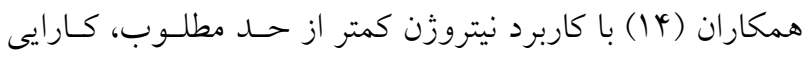

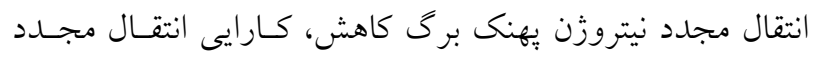
نيتروزن غلاف برى بدون تغيير و كارايى انتقال مجدد نيتـروزن

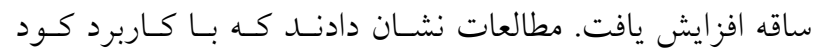
نيتروزن انتقال مجلد نيتروزن و جذب نيتروزن بعـد از كلـــهى

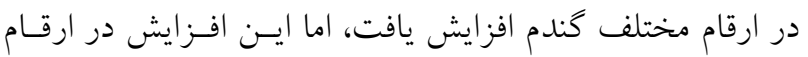

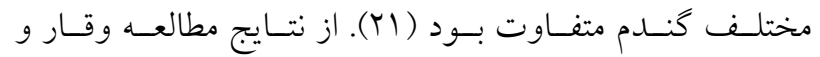
احسانزاده (Yr) جنين استنباط مى شود كه كندمهاى تترايلوئيـد

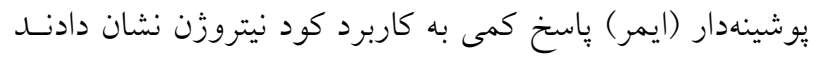
و انتقال نيتروزن كمترى نسبت به كندمهاى اصلاح شده داشتئند.

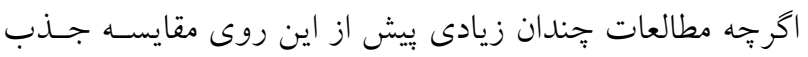

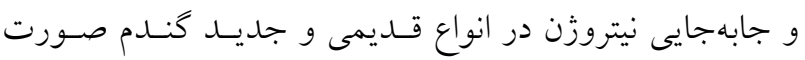

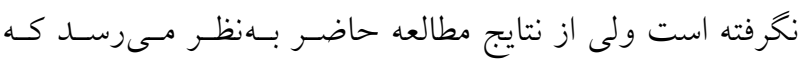

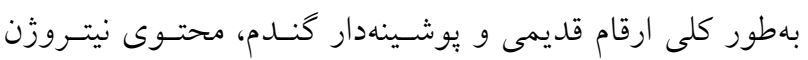

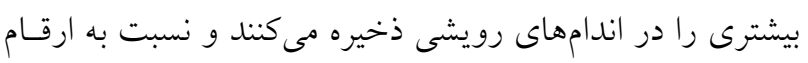

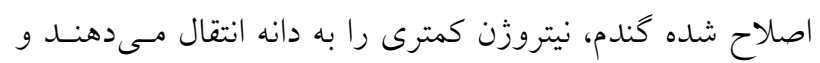
بههمين دليل انتقال مجدد نيتروزن كمترى نسبت به ارقام اصلاح

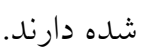
كاربرد كـود نيتـروزن باعـث افـزايش غلظـت فسـفر انـام رويشى و دانه در تمام زنوتيٍها شد، ولى ميزان اين افزايش در

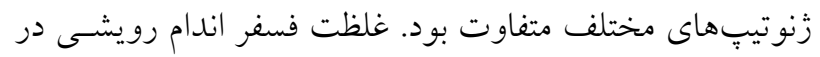

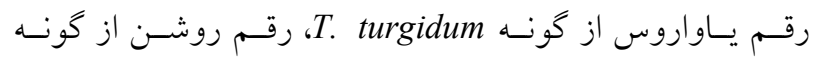
T. aestivum T. aethiopicum

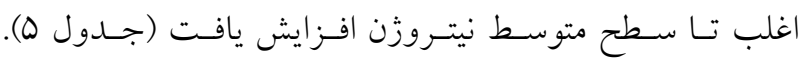

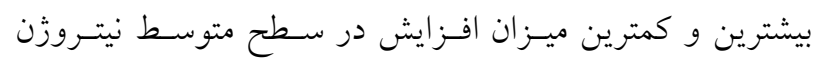

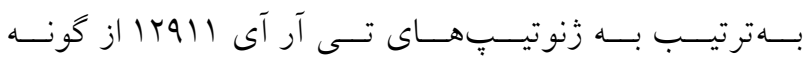

اندامهاى رويشى به دانه در مطالعات مختلف كزارش شده است

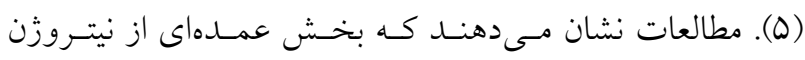

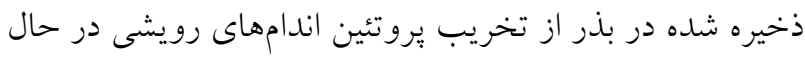

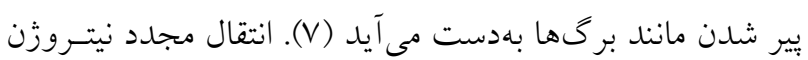

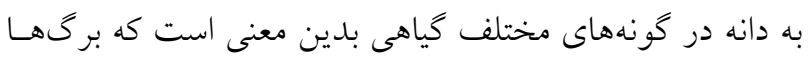

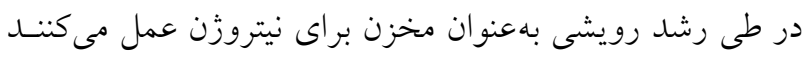
و در دوران ييرى حدود م1 درصد اين نيتروزن ذخيره شـده در

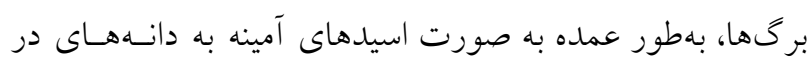

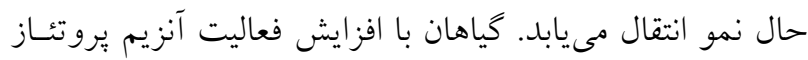

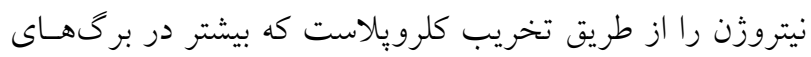

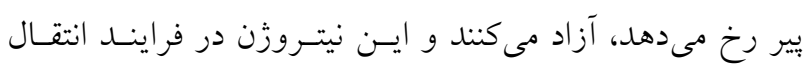

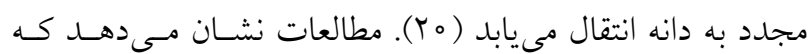

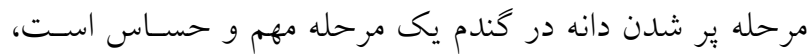

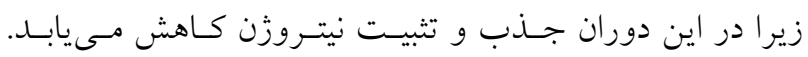

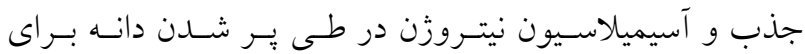
برطرف كردن نياز بالاى بذر براى نيتروزن كافى نيستيند. انتقـال

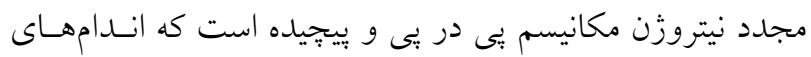

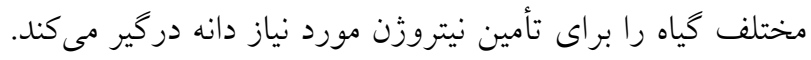

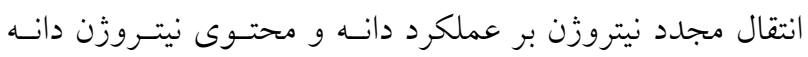
تأثير مهمى دارد. در غلات ميزان زيادى از نيتروزن دانه از انتقال

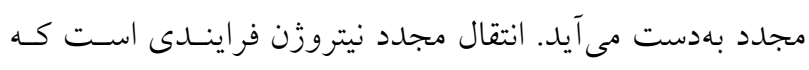

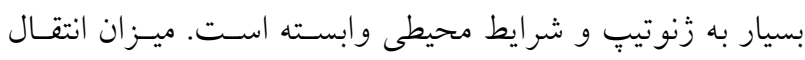

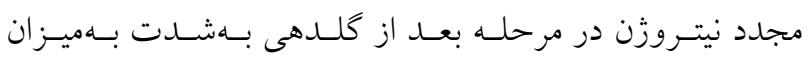

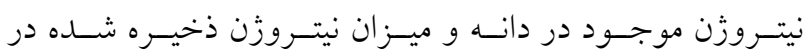

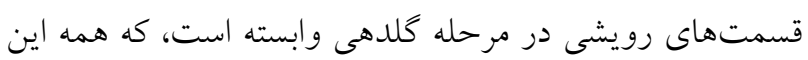

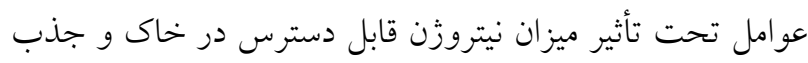

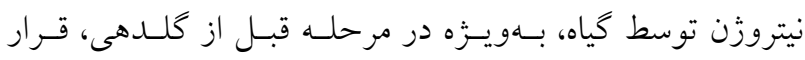

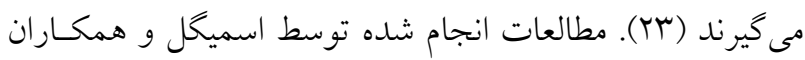

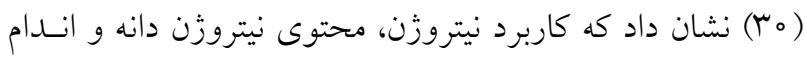

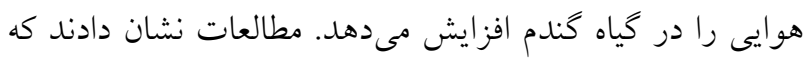

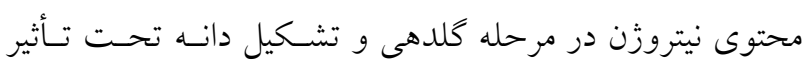
زنوتيب و ميزان كـاربرد كـود نيتـروزن اسـت (اس). در مطالعهـ 


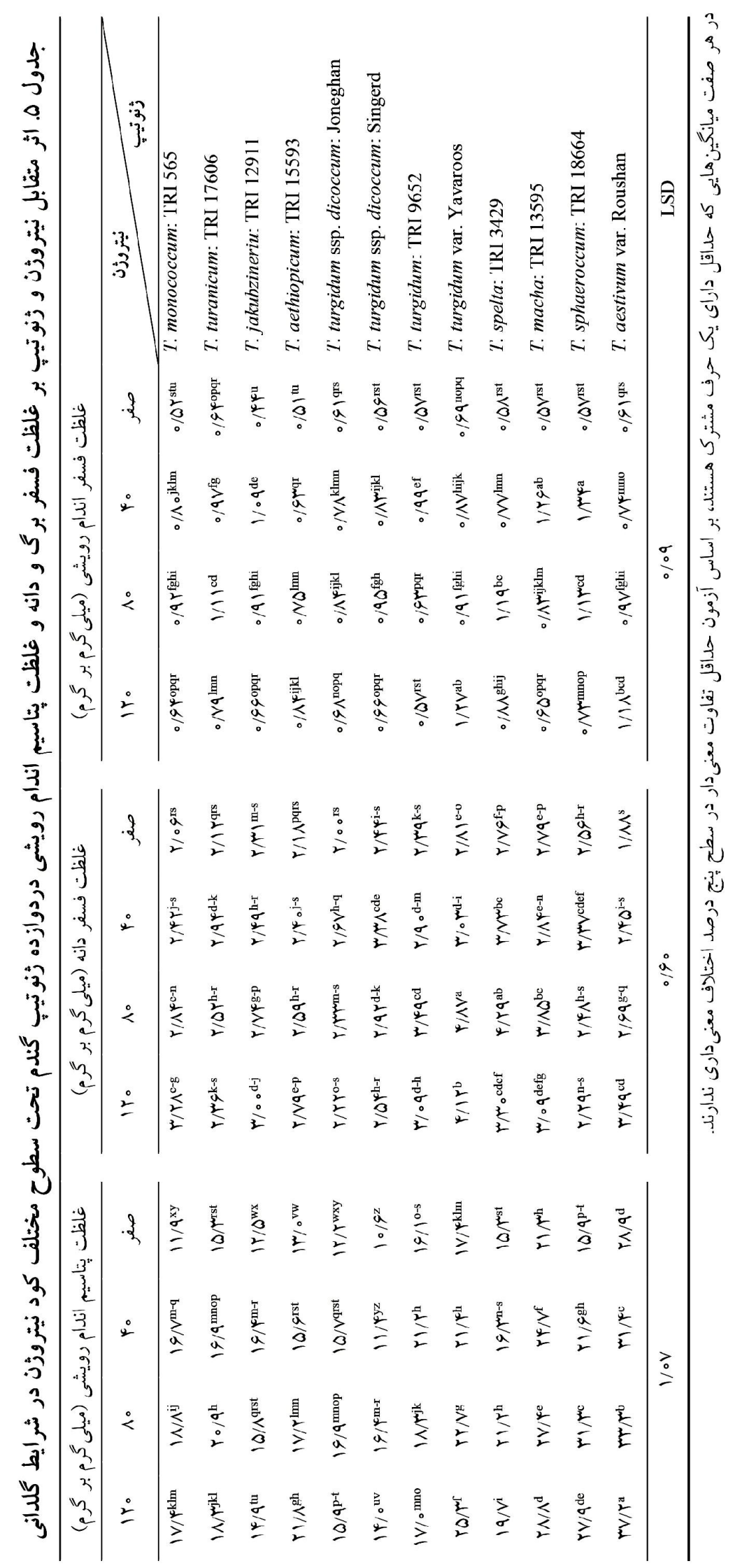


غلظت بتاسيم اندام رويشى را دارا بود. درحالى كـه گنــدمهـاى

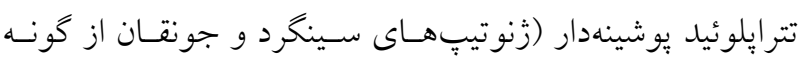
(T. turgidum ssp. dicoccum كمترين غلظت يّاسيم اندام رويشى را دارا بودند. غلظت يتاسيم دانه در ارقام اصلاح شده ياواروس و روشن (بهترتيب كونههاى (T. aestivum و با افزايش استعمال كود نيتـروزن

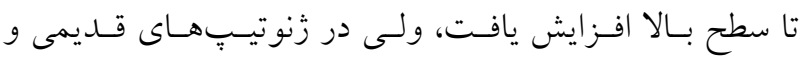

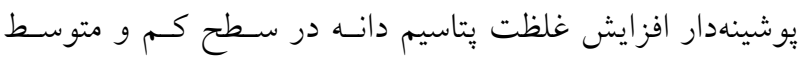

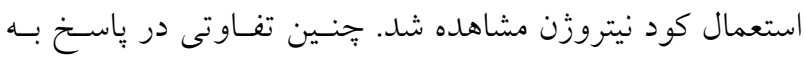

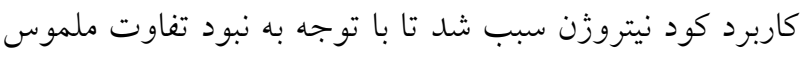
بين انواع كُندم در شرايط عــدم مصـرف كـود نيتـروزن، شـاهد

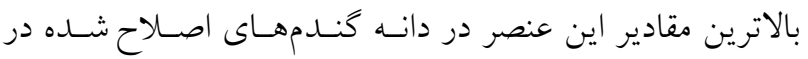

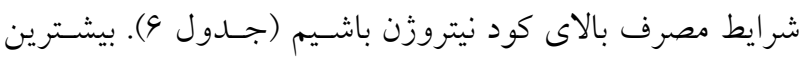

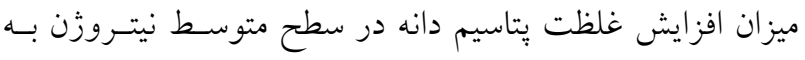

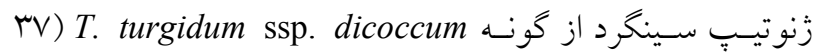

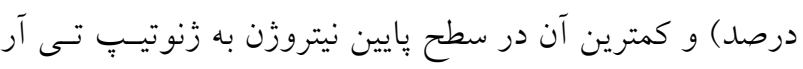

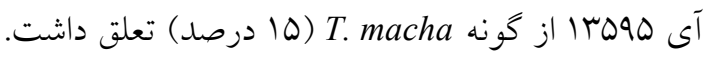

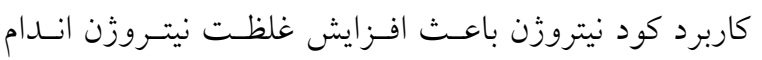

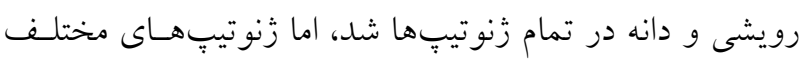

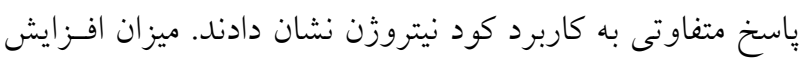

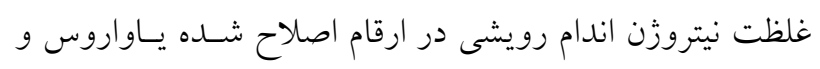

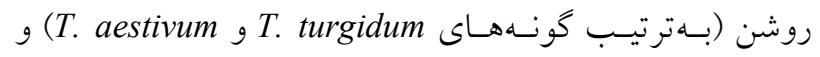

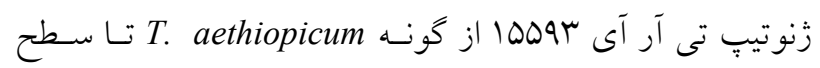

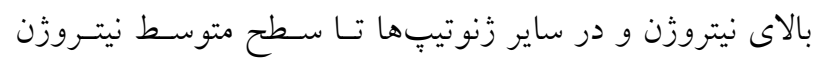

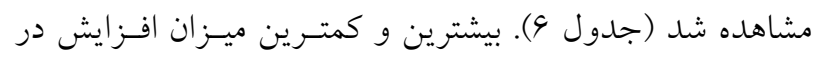

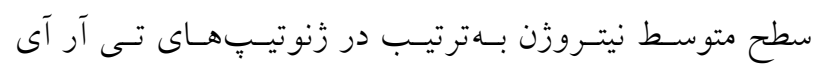

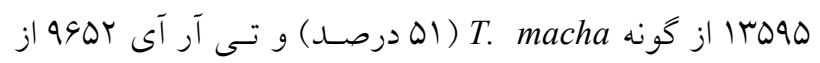

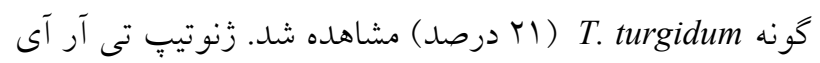

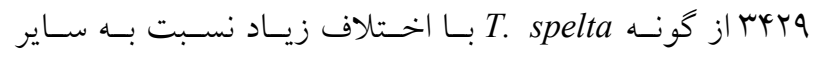
زنوتيِها بيشترين غلظت نيتـروزن انــام رويشسى را دارا بـود.

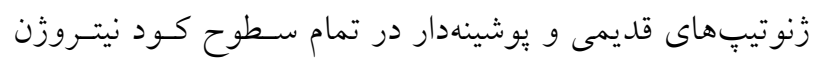

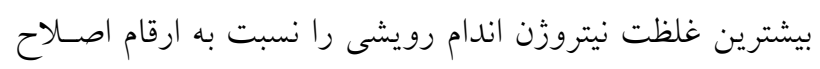

كونــه Takubzineriu

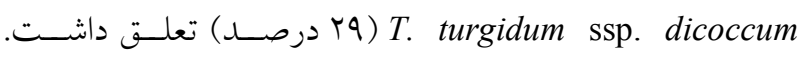

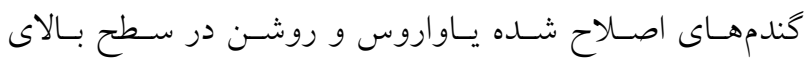

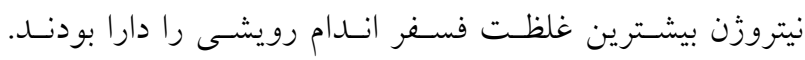

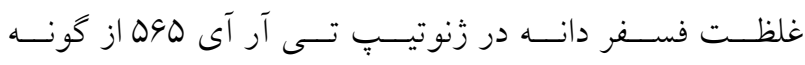
T. monococcum T. jakubzineriu

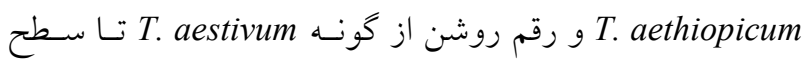

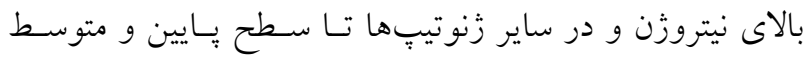
نيتروزن افزايش يافت (جـــول هام). بيشـترين و كمتـرين ميـزان

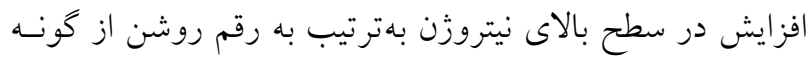

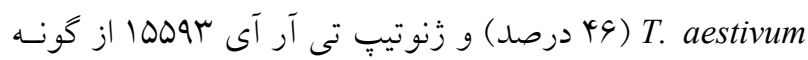

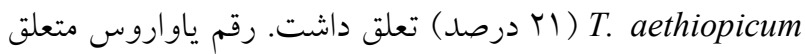

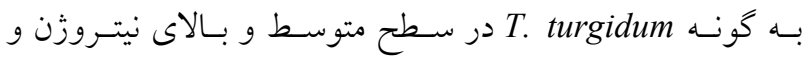

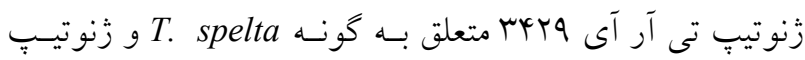

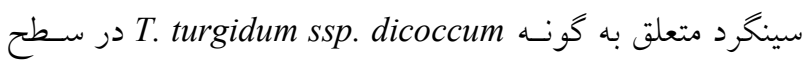

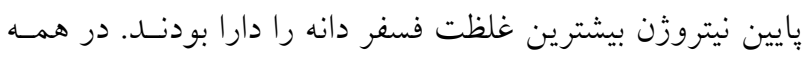

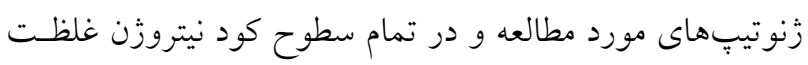

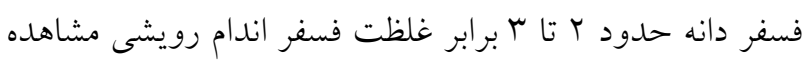
شد. غلظت يتاسيم اندام رويشى و دانـهـ در تمـام زنوتيـبِهــا بـا

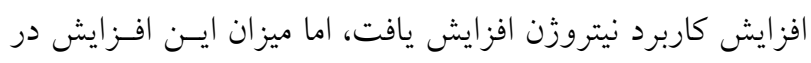

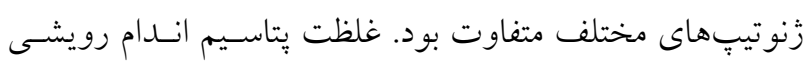

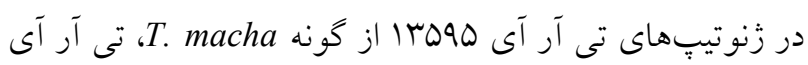

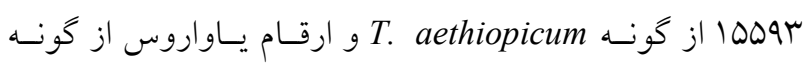

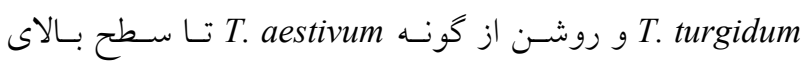
نيتروزن و در ساير زنوتيِها اغلب در سـطح متوسط نيتـروزن

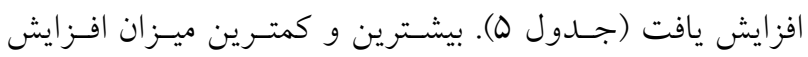
غلظت بتاسيم اندام رويشى در سطح متوسط نيتروزن بـهترتيـبـ

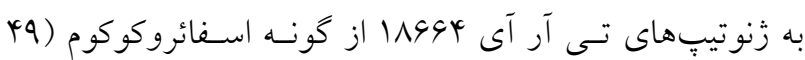

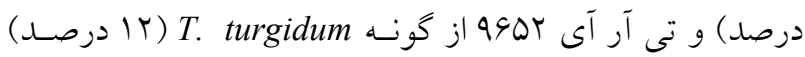
تعلق داشت. رقم روشن در تمام سطوح كود نيتـروزن بـالاترين 


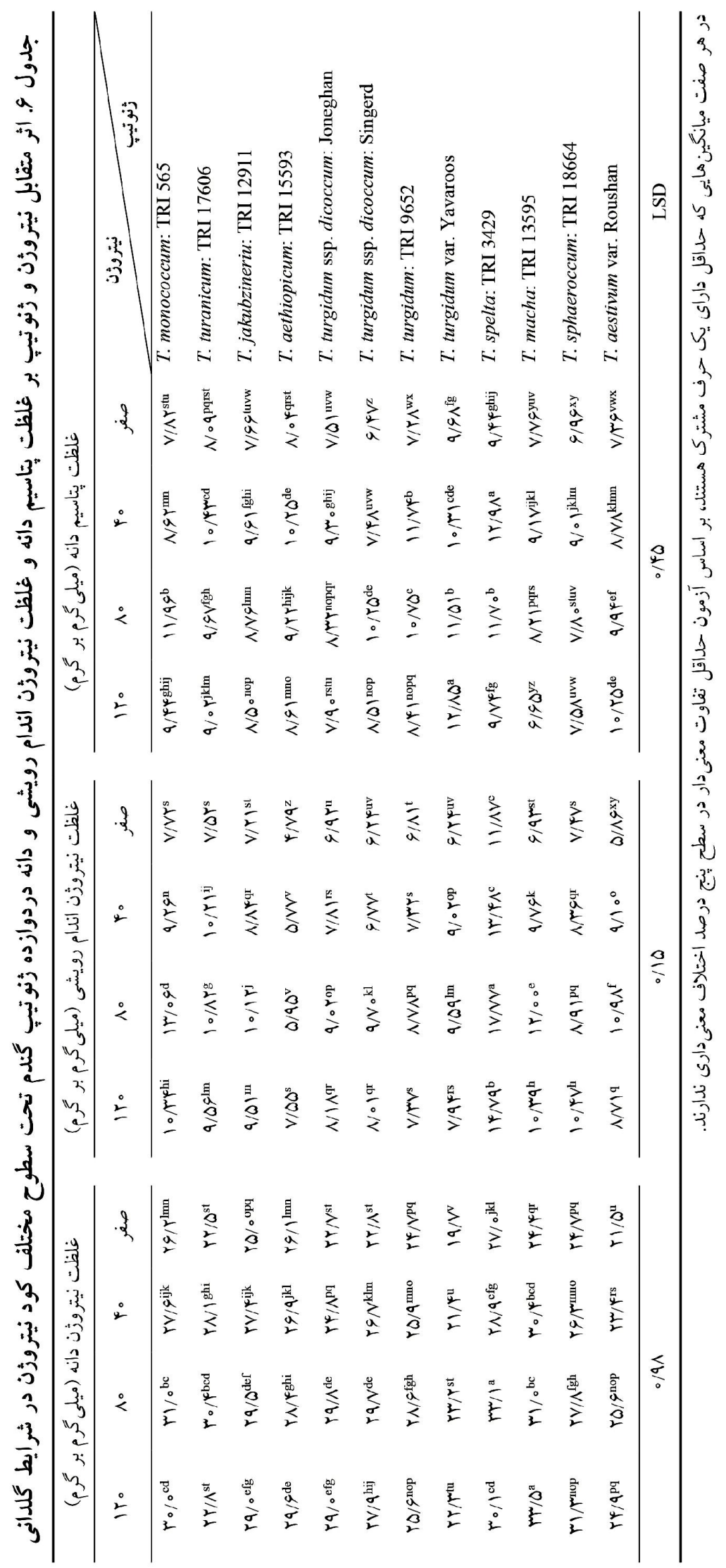


تأثير معنى دارى نداشت. عملكرد دانه با غلظت عناصـر در دانـه رابطه عكس دارد و در بسيارى از مطالعات تأثير معنى دار ميـزان

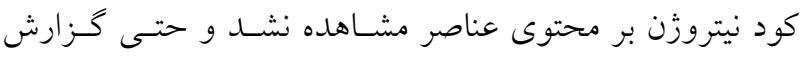
شده كه كاربرد كود نيتروزن باعت كاهش غلظت عناصر در دانه مىشود كه بهدليل اثر رقيقسازى ناشى از افزايش عملكـــد دانـهـ

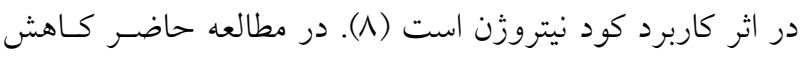

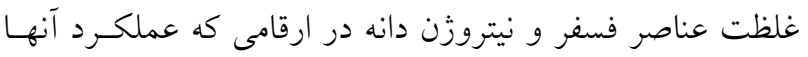

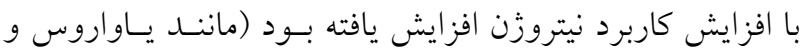
روشن) مى تواند بهعلت همين اثر رقيقسـازى عناصـر ناشسى از افزايش عملكرد باشد (جدولهاى ه و 9). با توجه به مشاهدات

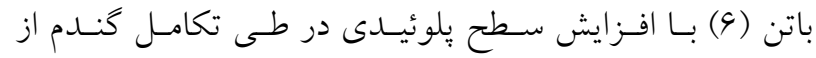

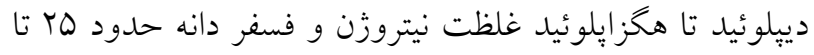

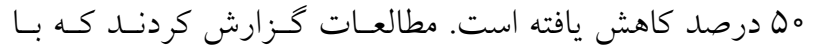

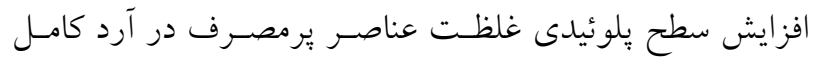

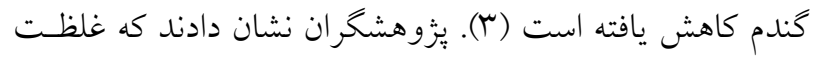

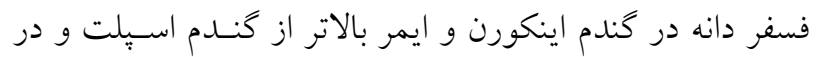

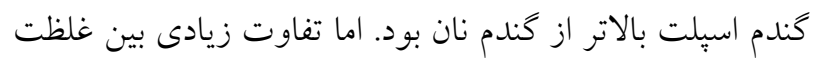

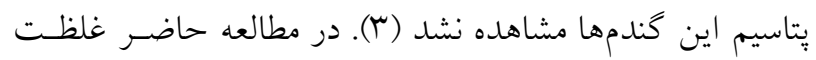

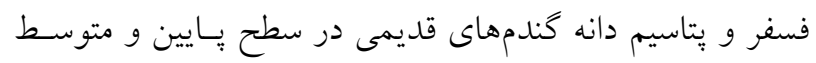

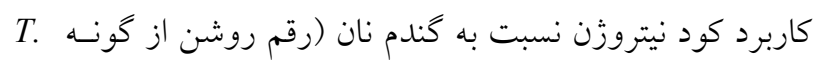
بالاتر بود، اما با افزايش كاربرد كود نيتـروزن نتيجـهـ (aestivum عكس (افزايش غلظت اين عناصر در دانه گنــدم نـان) مشـاهده

\section{نتيجه گيرى}

نتايج تأثير سطوح مختلف نيتـروزن بــر انتقـال مجــد نيتـروزن و فئون غلظت عناصـر فسـفر، بِتاسـيم و نيتـروزن انــام رويشسى و دانسه

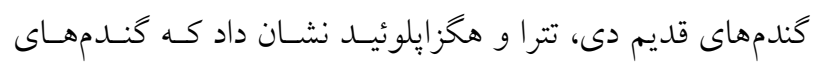

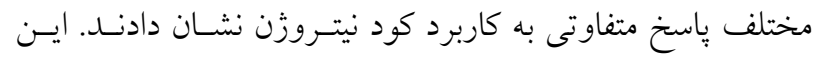
نتايج وجود تنوع زنتيكى زياد بين اين كَندمها را آشكار مى سئسازد.

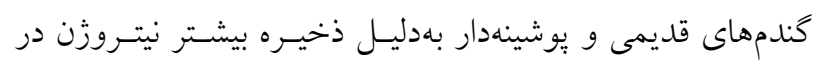

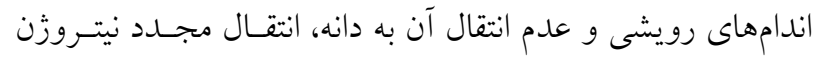

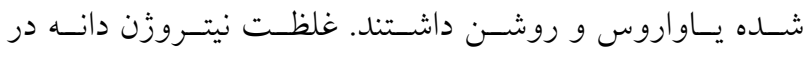

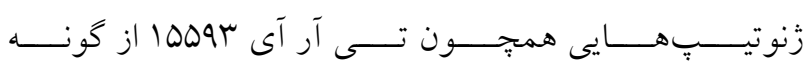
، T. macha T. aethiopicum

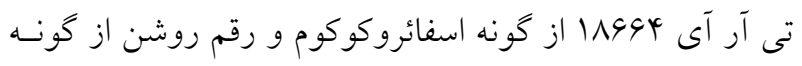

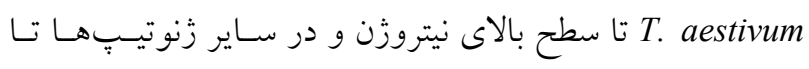

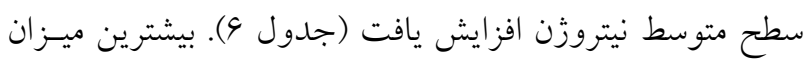

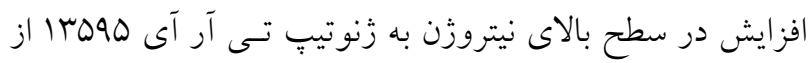

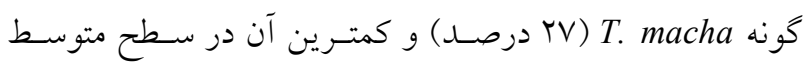

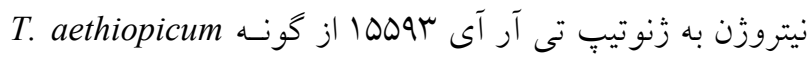

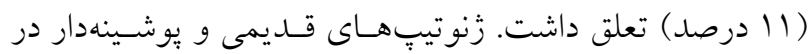

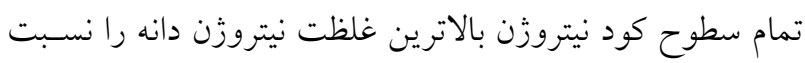

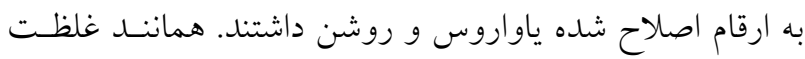
فسفر دانه، همه زُنوتيبٍهاى بهكار رفته در مطالعه حاضر تمايسل

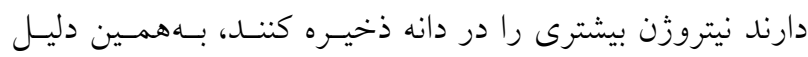

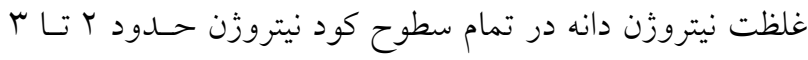
برابر غلظت نيتروزن اندام رويشى مشاهده شده است.

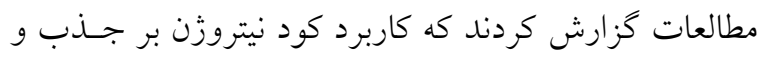

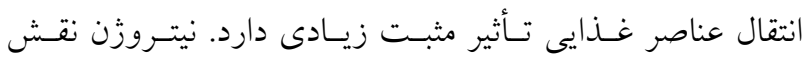

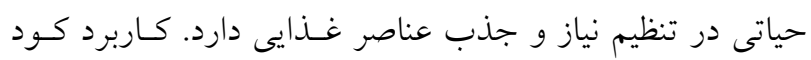

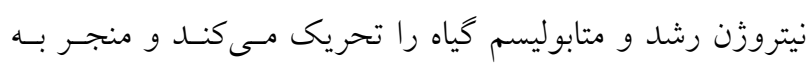

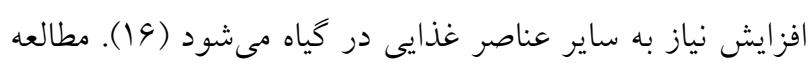
انجام شده توسط شاه و همكاران (Y9) نشان دادنــ كـه كـاربرد نيتروزن بهطور معنىدارى بر جذب و تجمع ساير عناصر معدنى

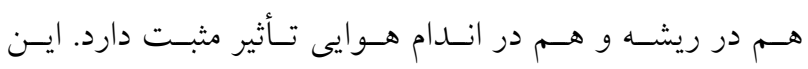

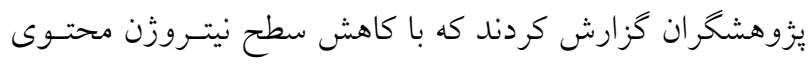

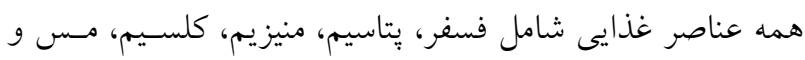

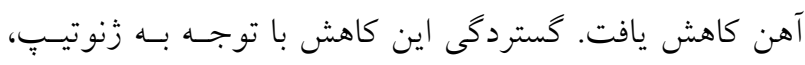

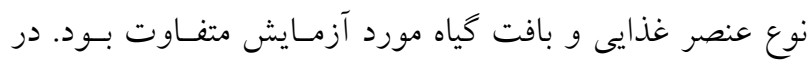

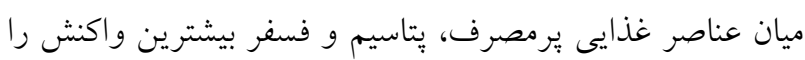
به كاربرد كود نيتروزن نشان دادند. با توجه به مشـاهدات فانـا و

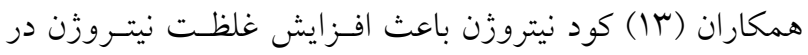

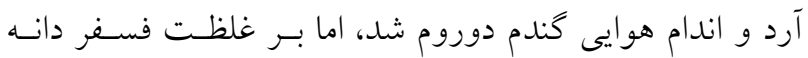




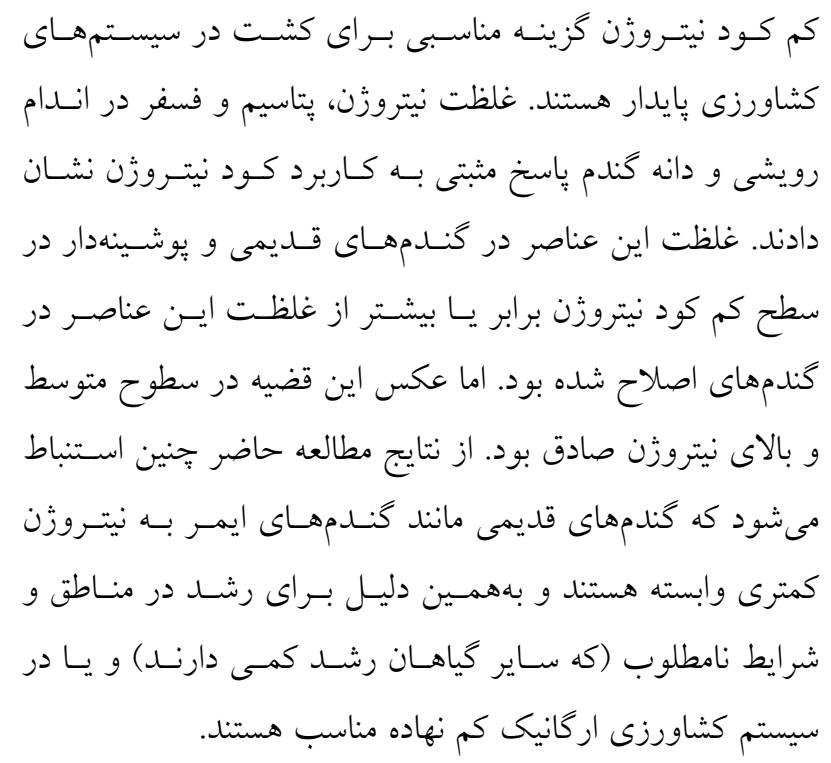

\section{منابع مورد استفاده}

1. Anwar, F., M. H. Siddiqui, S. S. Alghamdi, M. H. Al-Whaibi and A. Chandra. 2011. Nitrogen use- efficiency and crop production- A Mini Review. Journal of Science and Technology 6: 167-174.

2. Arduini, I., A. Masoni, L. Ercoli and M. Mariotti. 2006. Grain yield, and dry matter and nitrogen accumulation and remobilization in durum wheat as affected by variety and seeding rate. European Journal of Agronomy 25: 309-318.

3. Arzani, A. and M. Ashraf. 2017. Cultivated ancient wheats (Triticum spp.): A potential source of health-beneficial food products. Comprehensive Reviews in Food Science and Food Safety 16: 477-488.

4. Bahrani, A. and M. Haghjoo. 2010. Flag leaf role in $\mathrm{N}$ accumulation and remobilization as affected by nitrogen in a bread and durum wheat cultivars. American-Eurasian Journal of Agriculture and Environmental Sciences 8: 728-735.

5. Barraclough, P. B., R. Lopez-Bellido and M. J. Hawkesford. 2014. Genotypic variation in the uptake, partitioning and remobilization of nitrogen during grain-filling in wheat. Field Crop Research 156: 242-248.

6. Batten, G. D. 1986. The uptake and utilization of phosphorus and nitrogen by diploid, tetraploid and hexaploid wheats (Triticum spp.). Annals of Botany 58: 49-59.

7. Bouchet, A., A. Laperche, C. Bissuel-Belaygue, R. Snowdon, N. Nesi and A. Stahl. 2016. Nitrogen use efficiency in rapeseed. A review. Agronomy for Sustainable Development 36: 1-20.

8. Carvalho, M. G. J., E. M. Bonfim-Silva and T. J. A. Silva. 2016. Nitrogen and potassium in production, nutrition and water use efficiency in wheat plants. Cienc Investig Agrar 43: 442-451.

9. Coelho, C. P., L. A. Santos, R. P. Rangel, M. V. L. Sperandio, C. A. Bucher, S. R. Souza and M. S. Fernandes. 2016. Rice varieties exhibit different mechanisms for nitrogen use efficiency (NUE). Australian Journal of Agricultural Research 10: 342-352.

10. Dawson, J. C., D. R. Huggins and S. S. Jones. 2008. Characterizing nitrogen use efficiency in natural and agricultural ecosystems to improve the performance of cereal crops in low-input and organic agricultural systems. Field Crops Research 107: 89-101.

11. Dou, Z., S. Tang, G. Li, Z. Liu, C. Ding, L. Chen, S. Wang and Y. Ding. 2017. Application of nitrogen fertilizer at heading stage improves rice quality under elevated temperature during grain-filling stage. Crop Science 57: 2183-2192.

12. Ercoli, L., L. Lulli, M. Mariotti, A. Masoni and I. Arduini. 2008. Post-anthesis dry matter and nitrogen dynamics in durum wheat as affected by nitrogen supply and soil water availability. European Journal of Agronomy 28: 138-147.

13. Fana, G., H. Deressa, R. Dargie, M. Bogale, S. Mehadi and F. Getachew. 2012. Grain hardness, hectolitre weight, nitrogen and phosphorus concentrations of durum wheat (Triticum turgidum L.var. Durum) as influenced by nitrogen and phosphorus fertilisation. World Applied Sciences Journal 20: 1322-1327.

14. Gaju, O., V. Allard, P. Martre, J. LeGouis, D. Moreau, M. Bogard, S. Hubbart and M. J. Foulkes. 2014. Nitrogen partitioning and remobilization in relation to leaf senescence, grain yield and grain nitrogen concentration in wheat cultivars. Field Crops Research 155: 213-223. 
15. Gaju, O., J. DeSilva, P. Carvalho, M. J. Hawkesford, S. Griffiths, A. Greenland and M. J. Foulkes. 2016. Leaf photosynthesis and associations with grain yield, biomass and nitrogen-use efficiency in landraces, syntheticderived lines and cultivars in wheat. Field Crops Research 193: 1-15.

16. Gregorio, G. B., D. Senadhira, H. Htut and R. D. Graham. 2000. Breeding for trace mineral density in rice. Food and Nutrition Bulletin 21: 382-386.

17. Guarda, G., S. Padovan and G. Delogu. 2004. Grain yield, nitrogen-use efficiency and baking quality of old and modern Italian bread-wheat cultivars grown at different nitrogen levels. European Journal of Agronomy 21: 181-192.

18. Hossain, A. B. S., R. G. Stars, T. S. Cox and G. M. Paulsen. 1990. Desiccation tolerance and its relationship to assimilate partitioning in winter wheat. Crop Science 30: 622-627.

19. Hu, W., T. Ren, F. Meng, R. Cong, X. Li, P. J. White and J. Lu. 2019. Leaf photosynthetic capacity is regulated by the interaction of nitrogen and potassium through coordination of $\mathrm{CO}_{2}$ diffusion and carboxylation. Physiologia Plantarum 167: 418-432.

20. Kant, S., Y. M. Bi and S. J. Rothstein. 2011. Understanding plant response to nitrogen limitation for the improvement of crop nitrogen use efficiency. Journal of Experimental Botany 62: 1499-1509.

21. Kichey, T., B. Hirel, E. Heumez, F. Dubois and J. Le Gouis. 2007. In winter wheat (Triticum aestivum L.), postanthesis nitrogen uptake and remobilisation to the grain correlates with agronomic traits and nitrogen physiological markers. Field Crops Research 102: 22-32.

22. Kizilgecil, F., M. Yildirim and C. Akinci. 2016. Nitrogen use efficiency (NUE) changes in durum wheat parents and their F2 progenies under different nitrogen conditions. Journal of Agricultural Faculty of Gaziosmanpasa University 33: 96-102.

23. Kong, L., Y. Xie, L. Hu, B. Feng and S. Li. 2016. Remobilization of vegetative nitrogen to developing grain in wheat (Triticum aestivum L.). Field Crops Research 196: 134-144.

24. Makino, A. 2011. Photosynthesis, grain yield, and nitrogen utilization in rice and wheat. Plant Physiology 155: $125-129$.

25. Masoni, A., L. Ercoli, M. Mariotti and I. Arduini. 2007. Post-anthesis accumulation and remobilization of dry matter, nitrogen and phosphorus in durum wheat as affected by soil type. European Journal of Agronomy 26: 179-186.

26. Motamedi, M., H. Karimmojeni and G. F. Sini. 2016. Evaluation of allelopathic potential of safflower genotypes (Carthamus tinctorius L.). Journal of Plant Protection Research 56: 364-371.

27. Perchlik, M. and M. Tegeder. 2017. Improving plant nitrogen use efficiency through alteration of amino acid transport processes. Plant Physiology 175: 235-247.

28. Pujol, B., F. Renoux, M. Elias, L. Rival and D. Mckey. 2007. The unappreciated ecology of landrace populations: Conservation consequences of soil seed banks in Cassava. Biological Conservation 136: 541-551.

29. Shah, J. M., S. A. H. Bukhari, J. Zeng, X. Quan, E. Ali, N. Muhamma and G. Zhang. 2017. Nitrogen (N) metabolism related enzyme activities, cell ultrastructure and nutrient contents as affected by $\mathrm{N}$ level and barley genotype. Journal of Integrative Agriculture 16: 190-198.

30. Szmigiel, A., M. Kołodziejczyk, A. Oleksy and B. Kulig. 2016. Efficiency of nitrogen fertilization in spring wheat. International Journal of Plant Production 10: 447-456.

31. Todeschini, M. H., A. S. Milioli, D. M. Trevizan, E. Bornhofen, T. Finatto, L. Storck and G. Benin. 2015. Nitrogen use efficiency in modern wheat cultivars. Soil Science and Plant Nutrition 75: 351-361.

32. Vaghar, M. and P. Ehsanzadeh. 2018. Comparative photosynthetic attributes of emmer and modern wheats in response to water and nitrogen supply. Photosynthetica 56: 1224-1234.

33. Xu, G., X. Fan, and A. J. Miller. 2012. Plant nitrogen assimilation and use efficiency. Annual Review of Plant Biology 63: 153-182.

34. Yu, Q. G., J. Ye, S. N. Yang, G. R. Fu, J. W. Ma, W. C. Sun, L. N. Jiang and Q. Wang. 2013. Effects of nitrogen application level on rice nutrient uptake and ammonia volatilization. Rice Science 20: 139-147. 


\title{
Nitrogen Remobilization and N-P-K Concentration of Wheats of Different Ploidy Levels Respond Differently to Nitrogen Supply
}

\author{
S. Fatholahi ${ }^{1}$, P. Ehsanzadeh ${ }^{2^{*}}$ and H. Karimmojeni ${ }^{3}$
}

(Received: February 04-2020; Accepted: June 08-2020)

\begin{abstract}
Relationship of nitrogen $(\mathrm{N})$ supply to nitrogen remobilization and leaf and grain $\mathrm{P}, \mathrm{K}$, and $\mathrm{N}$ status of wheat lacks clarity. The present pot experiment was conducted to evaluate nitrogen remobilization and leaf and grain $\mathrm{P}, \mathrm{K}$, and $\mathrm{N}$ status of ancient wheats of different ploidy levels in response to nitrogen. The experiment was carried out in Fall $2017-$ Spring 2018 at the Isfahan University of Technology, Isfahan, Iran. The experiment was designed as a 3-replicate factorial completely random design with $\mathrm{N}$ fertilization treatment (at four levels of $0,18.66,37.33$, and $56 \mathrm{mg} \mathrm{N} \mathrm{kg}^{-1}$ soil) and genotype (consisting of 12 genotypes) as experimental factors. Nitrogen remobilization of the ancient and hulled wheats were increased when exposed to the low and medium $\mathrm{N}$ supplies. However, the Nitrogen remobilization of the standard durum and bread wheats were increased with increases in the $\mathrm{N}$ supply. Leaf and grain $\mathrm{P}$, leaf $\mathrm{N}$, and grain $\mathrm{K}$ concentrations responded positively to the $\mathrm{N}$ supply and ancient and hulled wheats equaled or exceeded those of the improved wheats particularly when grown in the absence of high $\mathrm{N}$ supplies. The presented data indicates that in conditions of nitrogen deficiency, the ancient wheats outperform improved wheats in terms of absorption and utilization of macronutrients.
\end{abstract}

Keywords: Remobilization, Einkorn, Emmer, Spelt

1, 2 and 3. PhD. Student, Professor, and Associate Professor, Respectively, Department of Agronomy and Plant Breeding, College of Agriculture, Isfahan University of Technology, Isfahan, Iran.

*: Corresponding Author, Email: ehsanzadehp@gmail.com 